RPP-49062, Rev. 0

\title{
CAST STONE TECHNOLOGY FOR THE TREATMENT AND IMMOBILIZATION OF LOW-ACTIVITY WASTE
}

\author{
H.J. Minwalla \\ Washington River Protection Solutions, LLC \\ Richland, WA 99352 \\ U.S. Department of Energy Contract DE-AC27-08RV14800
}

EDT/ECN: DRF UC:

Cost Center: Charge Code:

B\&R Code: Total Pages: 53

Key Words: Immobilization Treatment, LAW, Cast Stone, pre-conceptual design

Abstract: Cast stone technology is being evaluated for potential application in the treatment and immobilization fo Hanford low-activity waste. The purpose of this document is to provide background information on cast stone technology. The information provided in the report is mainly based on a preconceptual design completed in 2003.

TRADEMARK DISCLAIMER. Reference herein to any specific commercial product, process, or service by trade name, trademark, manufacturer, or otherwise, does not necessarily constitute or imply its endorsement, recommendation, or favoring by the United States Government or any agency thereof or its contractors or subcontractors.
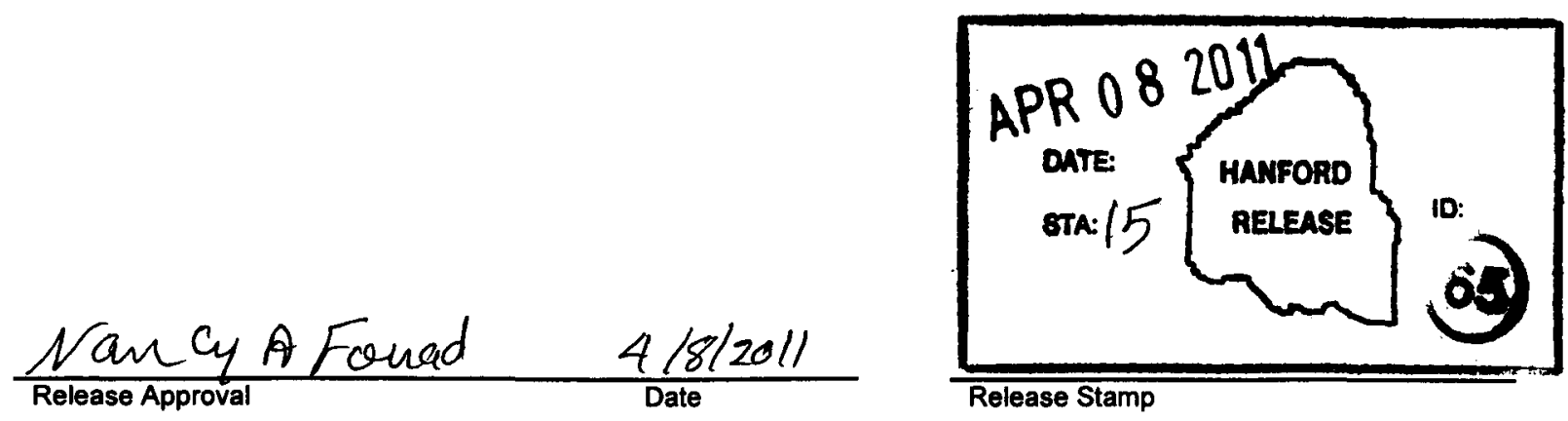

\section{Approved For Public Release}


RPP-49062, Rev 0

\section{CAST STONE TECHNOLOGY FOR THE TREATMENT AND IMMOBILIZATION OF LOW-ACTIVITY WASTE}

\section{Author:}

H. J. Minwalla

Washington River Protection Solutions, LLC

Date Published

April 2011

Prepared for the U.S. Department of Energy Office of River Protection

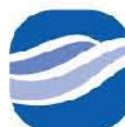

\section{washington river protectionsolutions}

\section{P. O. Box 850 \\ Richland, Washington}

This report was prepared as an account of work sponsored by an agency of the United States Government. Neither the United States Government nor any agency thereof, nor any of their employees, nor any of their contractors, subcontractors or their employees, makes any warranty, express or implied, or assumes any legal liability or responsibility for the accuracy, completeness, or any third party's use or the results of such use of any information, apparatus, product, or process disclosed, or represents that its use would not infringe privately owned rights. Reference herein to any specific commercial product, process, or service by trade name, trademark, manufacturer, or otherwise, does not necessarily constitute or imply its endorsement, recommendation, or favoring by the United States Government or any agency thereof or its contractors or subcontractors. The views and opinions of authors expressed herein do not necessarily state or reflect those of the United States Government or any agency thereof. 


\section{RPP-49062, Rev 0}

\section{PURPOSE}

The U.S. Department of Energy is building a Waste Treatment and Immobilization Plant to treat the approximately 55 million gallons of wastes from reprocessing spent nuclear fuel stored in 177 underground tanks at the Hanford Site in Washington State. Following treatment to remove key radionuclides to the maximum extent practical, approximately $90 \%$ of the tank waste mass (excluding water) will be immobilized as low-activity waste. The remainder will be immobilized as high-level waste.

The Waste Treatment and Immobilization Plant Low-Activity Waste vitrification plant should be capable of immobilizing approximately one-third of the total low-activity Hanford waste. A supplemental low-activity waste immobilization facility will be required to immobilize the remaining low-activity waste in order to complete the treatment mission on or before 2047 in accordance with the Hanford Federal Facility Agreement and Consent Order, which is also referred to in this report as the Tri-Party Agreement. Based on extensive reviews that started in 2002 by the Department of Energy, the Washington Department of Ecology, the U.S., the Environmental Protection Agency, and the Department of Energy contractors, four-candidate supplemental low-activity waste immobilization technologies remain under consideration.

1. Second Low-Activity Waste vitrification plant (RPP-48395, A Joule-Heated Melter Technology for the Treatment and Immobilization of Low-Activity Waste) (same technology as the LAW vitrification plant currently under construction).

2. Bulk Vitrification (RPP-48703, Bulk Vitrification Technology for the Treatment and Immobilization of Low-Activity Waste) (an in-container vitrification technology).

3. Cast Stone (RPP-49062, Cast Stone Technology for the Treatment and Immobilization of Low-Activity Waste) (a grout-based immobilization technology tailored to Hanford low-activity waste).

4. Fluidized Bed Steam Reforming (RPP-48903, Fluidized Bed Steam Reforming for Treating and Immobilizing Low-Activity Waste) (a thermal technology that produces a mineral waste form).

Four reports, as numbered above, have been prepared by Washington River Protection Solutions. Each report is designed to stand-alone or be used in conjunction with the others to provide background information about these technologies. The reports do not attempt to directly or indirectly recommend, compare, or contrast any one technology over the other. Rather, the goal is to present information as a high-level introduction to the four technologies, and assist the reader in further exploration of any given topic. Each of the reports will follow the same basic structure as outlined below.

- Common introduction providing background to the Office of River Protection mission.

- Introduction to the specific technology.

- Current state of knowledge for the technology.

- Current information needs.

- Risks and data needs.

- References. 
Note: The above sections are not numbered as each topic may require less or more sections to delineate the information on the topics.

This report is focused on Cast Stone Technology.

The information in this report is primarily digested from scientific information published in the literature, vendor information, independent reports, and studies funded by DOE. Information from those sources is presented in this report in a format and style intended to be understandable by non-technical readers yet to also be informative to DOE, regulators, and other technically informed readers.

The intent of the document is to summarize information in an easily assimilated format with references to source documents. The intent is not to compare the merits of Cast Stone to other technologies nor promote the use of Cast Stone. The selection decision regarding which technology will be used in accordance with applicable DOE Orders, the National Environmental Policy Act, and the Tri-Party.

This report describes known data gaps, technical risks, and other issues to be addressed through waste form qualification test programs or through subsequent maturation tests or engineering studies.

It should be noted that discussions of these technologies are based on pre-conceptual design information. As such the level of design descriptions is intended to be general. Current and accurate cost information specific to each technology is not available. 


\section{CAST STONE EXECUTIVE SUMMARY}

The U.S. Department of Energy is building a Waste Treatment and Immobilization Plant to treat the approximately 55 million gallons of wastes resulting from reprocessing irradiated nuclear fuel as part of the defense program. That waste is currently stored in 177 underground tanks at the Hanford Site in Washington State. Following treatment to remove key radionuclides to the maximum extent practical, approximately $90 \%$ of the tank waste mass (excluding water) will be immobilized as low-activity waste. The Department of Energy plans to immobilize and dispose of the low-activity waste stream on-site

The remainder of the tank waste, which will contain approximately $95 \%$ of the total tank waste radioactive inventory, will be vitrified as high-level waste. The vitrified high-level waste will be interim-stored on-site until a final disposal solution is identified. A simplified Hanford tank waste cleanup, treatment, and disposal flowsheet is depicted in Figure ES-1.

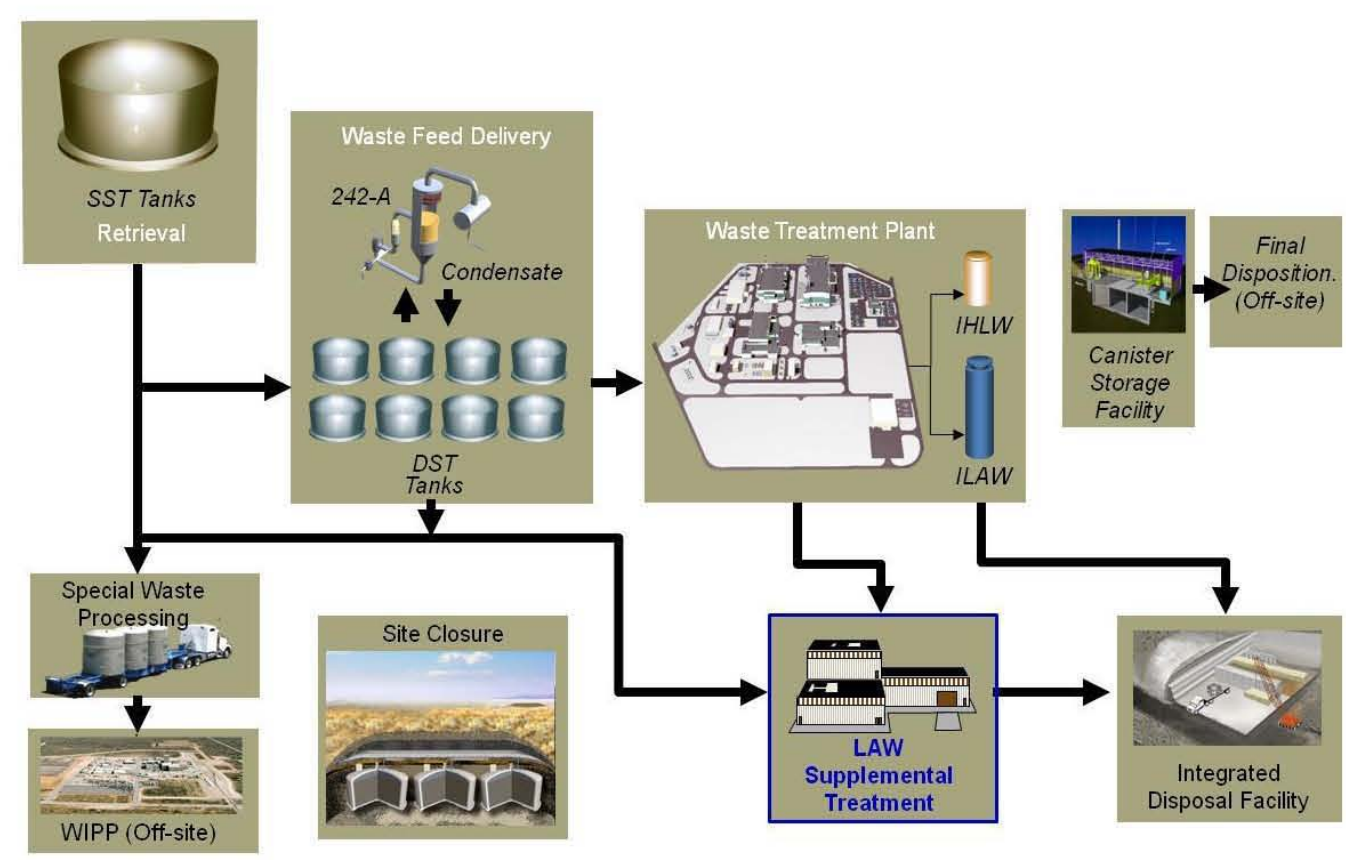

Figure ES-1. Hanford Nominal Tank Waste Treatment \& Disposition Flowsheet

The Waste Treatment and Immobilization Plant low-activity waste vitrification plant should be capable of vitrifying approximately one-third to one-half of the total low-activity waste. Supplemental low-activity waste immobilization will be required to immobilize the remainder. The Hanford Federal Facility Agreement and Consent Order, which is also referred to in this report as the Tri-Party Agreement or TPA, requires all Hanford tank waste treatment and immobilization to be completed by 2047 .

Because waste retrieved from the tanks is separated into high-level waste and low-activity waste fractions during pretreatment, unless the low-activity waste can be immobilized at the rate at which it is produced, the pretreatment processing and high-level waste vitrification will operate below the nominal production capacity throughput required to complete the mission on or before 
2047. Accordingly, the Department of Energy is currently considering ways to supplement the Waste Treatment and Immobilization Plant low-activity waste vitrification plant capacity in a manner that is protective of human health and the environment while also fiscally responsible.

Based on extensive reviews that started in 2002 by the Department of Energy, the Washington Department of Ecology (Ecology), and the U.S. Environmental Protection Agency (EPA), four candidate supplemental low-activity waste immobilization technologies are under consideration:

1. Second Low-Activity Waste Vitrification Plant (same technology as currently in the WTP).

2. Bulk Vitrification (an in-container vitrification technology).

3. Cast Stone (a grout-based immobilization technology tailored to Hanford lowactivity waste).

4. Fluidized Bed Steam Reforming (a thermal technology that produces a mineral waste form).

The decision regarding which of the four candidate technologies will be ultimately deployed will be made in accordance with Department of Energy Orders, the National Environmental Policy Act (NEPA), and the TPA. It is not known as of this writing which of those technologies will be selected.

The purpose of this report is to provide a summary level discussion of the various facets of the Cast Stone technology and the processes needed to implement it at Hanford. This report is based in part on a 2010 pre-conceptual engineering study (RPP-RPT-46668, Supplemental Treatment Pre-Conceptual Engineering Review), that explored supplemental treatment and immobilization options for the Hanford tank wastes. The information in RPP-RPT-46668, for a Cast Stone (solidification) facility, was developed primarily from RPP-RPT-26689, Containerized Cast Stone Facility Pre-Conceptual Engineering Report, completed in 2003.

Cast stone is a grout, that can be made from sulfate-resistant, Portland Type I/II cement; a pozzolanic material (Class F fly ash); and blast furnace slag. Waste is included as part of the mix. Portland cement is usually the base ingredient, with additions of pozzolanic cements and getters of various types. Pozzolanic materials are often non-radioactive, waste materials (e.g., fly ash or blast furnace slag) that aid in retaining waste materials and forming a solid monolith.

The Cast Stone system is a grout based simple solidification process that receives the (pretreated) LAW stream and produces a containerized, cement-based, waste form that meets the waste acceptance criteria for the Integrated Disposal Facility. Cast stone technology is a variation of the cement-based grout technology with different waste formulations and preparation methods to allow for the increased capture of technetium-99. The Cast Stone system is a non-thermal process that does not generate large volumes of secondary waste. The Cast Stone process does not destroy nitrates and therefore does not produce oxides of nitrogen, which in thermal processes has to be managed and treated. And because Cast Stone technology is a non-thermal process, it does not vaporize contaminants to the off-gas system. Additionally, Cast Stone technology has few required safety related structures, systems or components (SSCs) and associated mitigating safety controls.

Cast stone is extensively used in the commercial and government sectors for a wide range of low-level and intermediate-level radioactive waste operations. The technology (grout program) 
was evaluated at Hanford in a full-scale capacity in the late 1980s through the early 1990 s but only for a limited range of actual waste. A similar application of the technology is currently being used at the Saltstone Facility at Savannah River Site to encapsulate low-activity waste. For Hanford, other solidification technologies with different non-cement based formulations could be considered, such as Ceramicrete (phosphate and magnesium salt grout form) and geopolymer (duralith alkali aluminosilicate).

The primary concern with grout-based solidification technologies (such as Cast Stone) is related to the retention of technetium-99 and waste loading. A 2003 preliminary risk analysis indicated the technetium-99 leach rate for the Cast Stone immobilized low-activity waste exceeded that of the reference WTP ILAW glass by approximately three orders of magnitude. However, recent advancements in formulation chemistry have improved the performance. Recent SRS tests predict that the reducing atmosphere provided by blast furnace slag added in the Saltstone cementitious waste form for that site would retain technetium-99 for more than 10,000 years.

There is no ongoing testing being performed to further develop Cast Stone hardware or test Hanford LAW form. However, Pacific Northwest National Laboratory is testing Waste Immobilization and Treatment Plant secondary waste streams to obtain information about the new Cast Stone waste formulations to assess compliance with the Hanford waste acceptance criteria for disposal at the Integrated Disposal Facility. Adequate constituent retention is the driver to optimum waste loading. If low waste loadings are needed to obtain constituent retention, the volume of waste and the footprint of the Integrated Disposal Facility will increase along with final disposal costs. 


\section{TABLE OF CONTENTS}

PURPOSE ii

CAST STONE EXECUTIVE SUMMARY …............................................................ iv

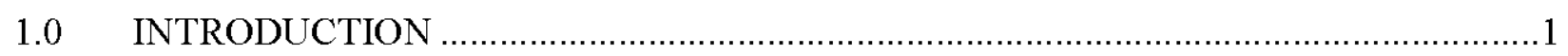

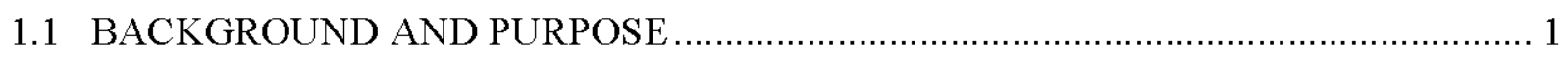

1.2 WHAT IS HANFORD TANK WASTE? ............................................................ 2

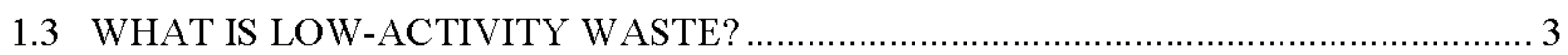

1.4 WHY IS ADDITIONAL WTP LAW IMMOBILIZATION CAPACITY NECESSARY?5

1.5 HOW WERE THE CANDIDATE LAW TECHNOLOGIES SELECTED? .................... 6

1.6 REGULATORY REQUIREMENTS FOR ON-SITE DISPOSAL OF LAW .................. 7

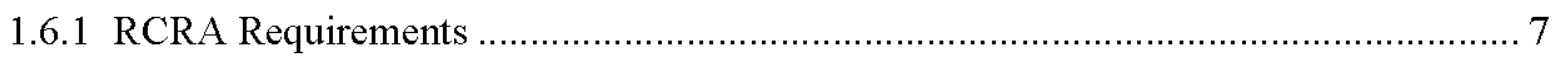

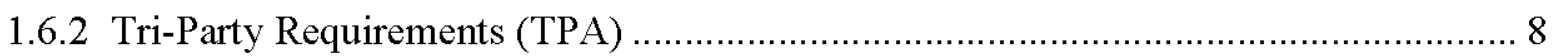

1.6.3 DOE Manual 435.1-1 Waste Incidental to Reprocessing (WIR) ............................ 8

1.6.4 DOE Manual 435.1-1 Disposal Authorization................................................ 9

1.6.5 IDF Waste Acceptance Criteria Requirement............................................... 9

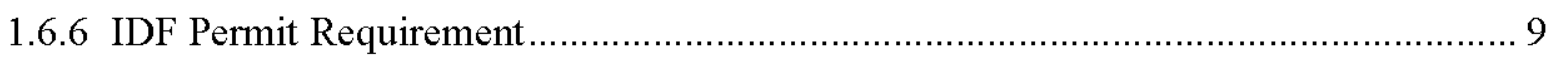

1.7 DETERMINING WASTE FORM PERFORMANCE .......................................... 10

1.7.1 Tests Used to Predict Long-Term Waste Form Performance............................... 10

1.7.2 Performance Objectives Used to Evaluate Performance Assessment Results............ 13

1.8 DESIRED ATTRIBUTES OF SELECTED TECHNOLOGIES ............................... 16

$2.0 \quad$ Introduction to Cast Stone Technology ............................................................... 17

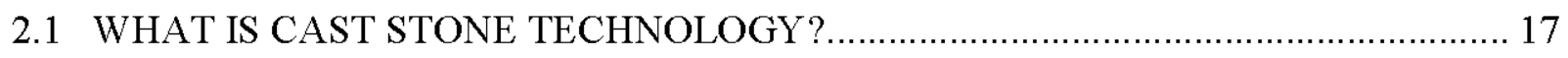

2.2 WHY IS CAST STONE BEING EVALUATED FOR POSSIBLE USE AT HANFORD?17

2.3 HOW DOES THE CAST STONE PROCESS WORK? .......................................... 17

2.3.1 Feed Preparation Requirements ..................................................................... 18

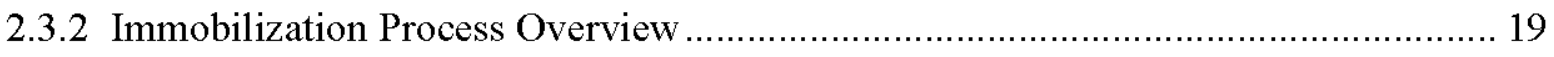

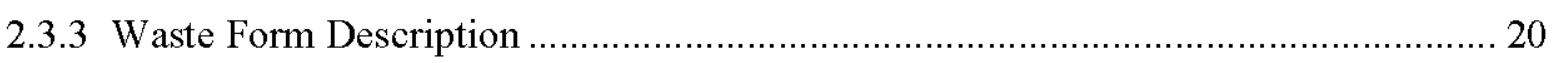

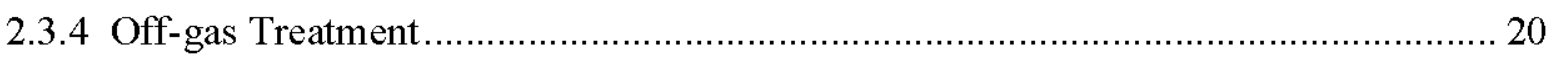

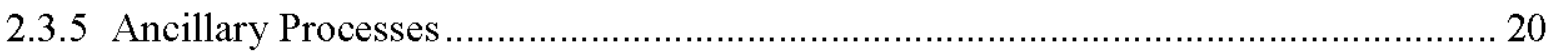

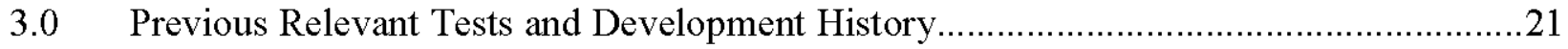

3.1 OVERVIEW OF PREVIOUS RELEVANT TESTS AND DEVELOPMENT HISTORY21

3.2 PREVIOUS USES OUTSIDE THE DOE COMPLEX …........................................ 22

4.0 Current State of Knowledge Using Cast Stone Technology for Hanford LAW ..............23 
4.1 HOW CAST STONE MIGHT FIT INTO THE HANFORD TANK WASTE

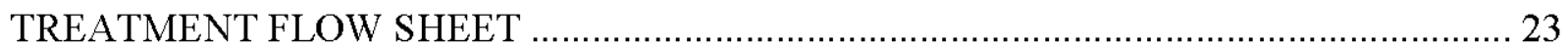

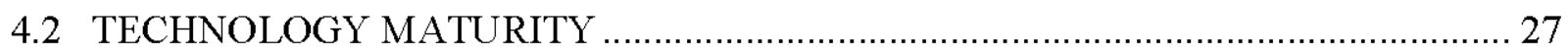

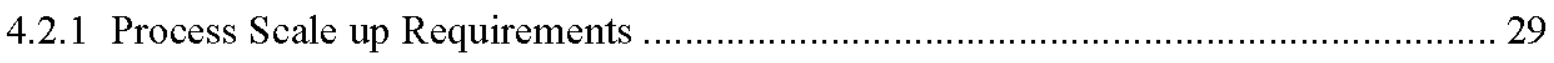

4.3 PROCESS SAFETY CONSIDERATIONS AND CONCERNS …………………........ 30

4.4 COST CONSIDERATIONS AND CONCERNS ………………............................... 30

4.5 WASTE FORM CHARACTERISTICS INCLUDING STRENGTHS, WEAKNESSES

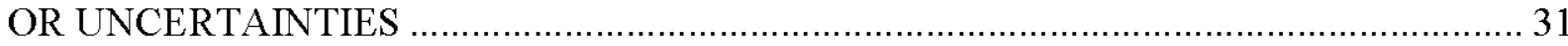

4.6 OFF-GAS TREATMENT REQUIREMENTS AND CONSTITUENTS OF OFF-GAS

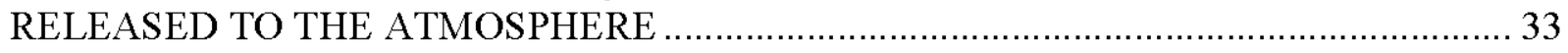

4.7 SECONDARY WASTE STREAMS AND THEIR MANAGEMENT............................ 33

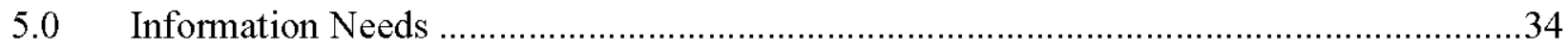

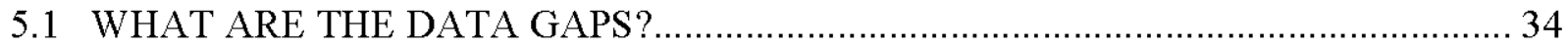

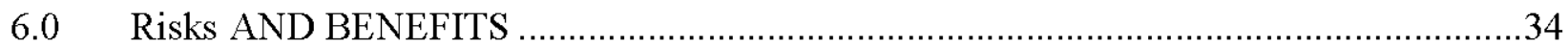

6.1 KEY TECHNICAL AND PROGRAMMATIC RISKS ……………………….......... 34

6.2 BENEFITS AND PRINCIPAL ADVANTAGES ...................................................... 35

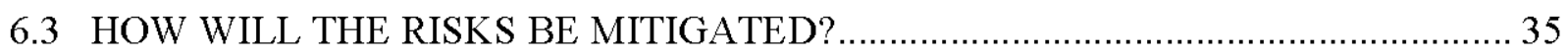

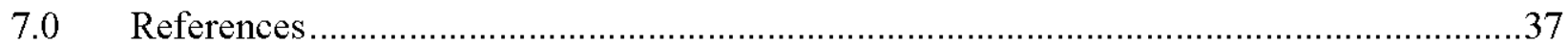

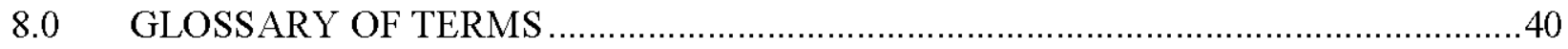

TABLE OF FIGURES

Figure ES-1. Hanford Nominal Tank Waste Treatment \& Disposition Flowsheet ......................iv

Figure 1-1. Hanford Nominal Tank Waste Treatment \& Disposition Flowsheet..........................2

Figure 1-2. Radionuclides Make Up a Small Fraction of Hanford Tank Waste.......................... 3

Figure 1-3. Depiction of Basic Pretreatment Processes to Remove Key Radionuclides from Hanford Tank Waste and Produce LAW Feed for Immobilization ............................5

Figure 1-4. Eight Steps Assumed in Performance Assessment Groundwater Pathway Models . 14

Figure 2-1. Schematic of Potential Cast Stone Process System (RPP-RPT-48092, Figure 4-25)

Figure 4-1. Process Flow Diagram for Containerized Cast Stone (RPP-RPT-46668, Figure 616)

Figure 4-2. Integrated Summary Schedule for Technology Readiness Level and Critical Decision Process (RPP-RPT-48092, Figure 2-1) 


\section{TABLE OF TABLES}

Table 1-1. Principal Waste Form Test Protocols 11

Table 1-2. Key Performance Objectives for Performance Assessment .................................. 15

Table 3-1. Technology Readiness Level Summary for Cast Stone System

Al

\section{LIST OF TERMS AND ABBREVIATIONS}

\begin{tabular}{|c|c|}
\hline ALARA & As Low As Reasonably Achievable \\
\hline ANSI & American National Standards Institute \\
\hline ANS & American National Standards \\
\hline ASTM & American Society for Testing Materials \\
\hline BPP & Bismuth Phosphate Process \\
\hline CERCLA & Comprehensive Environmental Response, Compensation, and Liability Act \\
\hline $\mathrm{Cs}$ & cesium \\
\hline $\mathrm{Cr}$ & chromium \\
\hline DET & Determination of Equivalent Treatment \\
\hline DOE & U.S. Department of Energy \\
\hline DOT & U.S. Department of Transportation \\
\hline EIS & Environmental Impact Statement \\
\hline EPA & U.S. Environmental Protection Agency \\
\hline EFT & Effluent Treatment Facility \\
\hline FBSR & Fluidized Bed Steam Reforming \\
\hline HEPA & High-Efficiency Particulate Air \\
\hline HLW & High-Level Waste \\
\hline HVAC & Heating, Ventilating, And Air Conditioning \\
\hline ILAW & Immobilized Low-Activity Waste \\
\hline Ecology & Washington Department of Ecology \\
\hline IDF & Integrated Disposal Facility \\
\hline INL & Idaho National Laboratory \\
\hline LAW & Low-Activity Waste \\
\hline LDR & Land Disposal Restrictions \\
\hline LLW & Low-Level Waste \\
\hline LERF & Liquid Effluent Retention Facility \\
\hline LFRG & Low-Level Waste Federal Review Group \\
\hline $\mathrm{Na}$ & sodium \\
\hline NEPA & National Environmental Policy Act of 1969 \\
\hline NRC & U.S. Nuclear Regulatory Commission \\
\hline ORNL & Oak Ridge National Laboratory \\
\hline ORP & Office of River Protection \\
\hline $\mathrm{PCT}$ & Product Consistency Test \\
\hline PNL & Pacific National Laboratory \\
\hline PNNL & Pacific Northwest National Laboratory \\
\hline PUF & Pressure Unsaturated Flowthrough Test \\
\hline PUREX & Plutonium-Uranium Extraction \\
\hline RCRA & Resource Conservation and Recovery Act \\
\hline
\end{tabular}


RPP-49062, Rev 0

$\begin{array}{ll}\text { REDOX } & \text { Reduction Oxidation } \\ \text { ROD } & \text { Record of Decision } \\ \text { RPP } & \text { River Protection Project } \\ \text { Sr } & \text { strontium } \\ \text { SPFT } & \text { Single Pass Flowthrough Test } \\ \text { SSC } & \text { structures, systems, and components } \\ \text { SRS } & \text { Savannah River Site } \\ \text { Tc } & \text { technetium } \\ \text { TCLP } & \text { Toxicity Characteristic Leaching Procedure } \\ \text { TPA } & \text { Tri-Party Agreement } \\ \text { TRA } & \text { Technology Readiness Assessment } \\ \text { TRL } & \text { Technology Readiness Level } \\ \text { TWRS } & \text { Tank Waste Remediation System } \\ \text { WVDP } & \text { West Valley Disposal Plant } \\ \text { WTP } & \text { Waste Treatment and Immobilization Plant } \\ & \\ \text { Units } & \\ \text { C } & \text { Celsius } \\ \text { Ci } & \text { Curies } \\ \text { F } & \text { Fahrenheit } \\ \text { Gmol } & \text { gram-mole } \\ \text { Kg } & \text { kilograms } \\ \text { Ml } & \text { milliliter } \\ \text { M } & \text { molar } \\ \text { MT } & \text { Metric ton } \\ \text { MTGD } & \text { metric tons of glass per day } \\ \text { wt } \% & \text { weight percent }\end{array}$




\subsection{INTRODUCTION}

\subsection{BACKGROUND AND PURPOSE}

The United States Department of Energy (U.S. DOE) is currently storing over 55 million gallons of wastes in underground storage tanks at it Hanford Site in Washington State. The DOE plans to separate the wastes into a High-Level Waste (HLW) stream and a Low-Activity Waste (LAW) stream. The HLW stream will be vitrified and ultimately disposed of off-site. Following treatment to remove key radionuclides to the maximum extent practical, the LAW stream will be immobilized for on-site disposal. Because tank wastes include both radioactive and hazardous waste constituents, the LAW will be treated, immobilized, and disposed of in a manner that meets performance objectives comparable to those in the U.S. Nuclear Regulatory Commission (U.S. NRC) regulations ${ }^{1}$ for the disposal of Low-Level Waste (LLW) ${ }^{2}$ and Resource Conservation and Recovery Act (RCRA) Land Disposal Restriction (LDR) requirements.

The DOE is currently building a LAW vitrification plant as part of the Waste Treatment and Immobilization Plant (WTP) that will convert a portion of the projected LAW waste stream into glass. The LAW Vitrification plant does not have the throughput capacity to vitrify all of the LAW. Accordingly, DOE is evaluating several immobilization techniques that could potentially be used to supplement the WTP LAW vitrification plant and convert the LAW into a solid waste form that safely meets applicable disposal requirements. Figure 1-1 depicts a nominal Hanford River Protection Project (RPP) flowsheet and indicates how supplemental LAW immobilization fits into the overall flowsheet regardless of the technology deployed.

The immobilization technologies currently under consideration include:

- Second $\left(2^{\text {nd }}\right)$ LAW vitrification;

- Cast Stone Technology (grout-based waste form tailored to Hanford LAW);

- Bulk Vitrification (in-container vitrification technology); and

- Fluidized Bed Steam Reforming (FBSR) (thermal process producing a mineral waste form).

The decision regarding which of the four technologies identified above will be ultimately deployed to supplement WTP LAW vitrification will be made in accordance with DOE Orders, NEPA, and the Ecology, EPA, and DOE, 1989, Hanford Federal Facility Agreement and Consent Order (Ecology et al. 1989) also known as the Tri-Party Agreement (TPA). It is not known as of this writing which technology will be selected. Discussions of these technologies are based on pre-conceptual design information. As such the level of design descriptions is general and specific cost information is not available.

\footnotetext{
${ }^{1} \mathrm{DOE}$ is not subject to NRC regulations for LAW waste treatment and disposition activities at Hanford; however, DOE does consult with the NRC on the classification of LAW as low-level waste and certain sections of NRC regulation 10 CFR Part 61 are used in the classification processes.

${ }^{2}$ Note that while LLW and LAW are essentially the same relative to radioactivity, the term LAW only applies to DOE tank waste that has been pretreated to remove key radionuclides.
} 


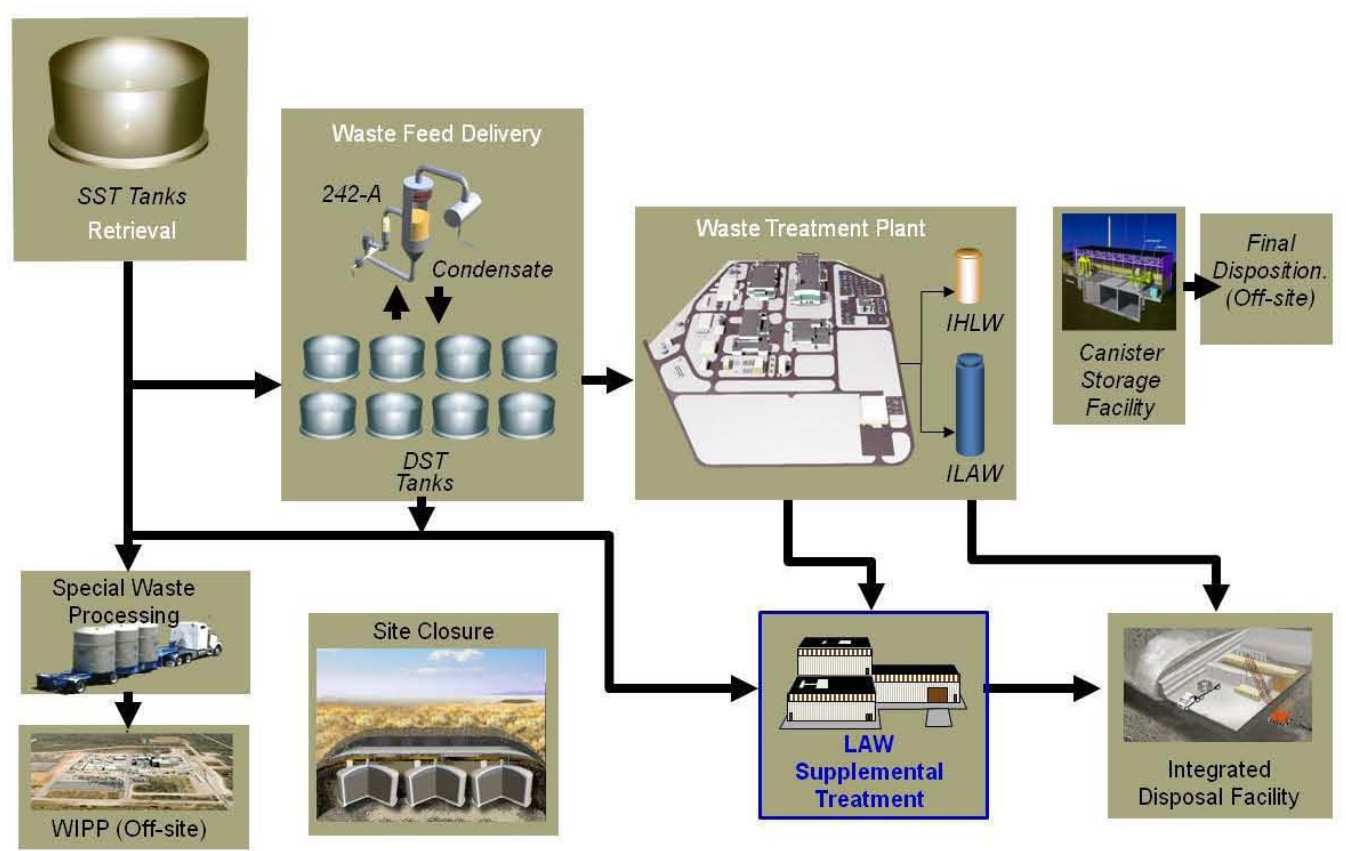

Figure 1-1. Hanford Nominal Tank Waste Treatment \& Disposition Flowsheet

\subsection{WHAT IS HANFORD TANK WASTE?}

The 177 Hanford underground storage tanks managed under the RPP contain over 55 million gallons of liquid (referred to as supernatant), saltcake, and sludge wastes, much of which was generated during the reprocessing of nuclear fuel to produce weapons grade plutonium $(\mathrm{Pu})$ for national defense. A variety of irradiated nuclear fuel reprocessing and chemical separations processes and campaigns were conducted at Hanford between 1945 and 1989, which resulted in highly complex chemical wastes in the Hanford tanks. Moreover, because Hanford started operations during World War II when stainless steel was in high demand, the Hanford tanks were constructed of carbon steel. The use of carbon steel required that the acidic reprocessing wastes be neutralized with sodium hydroxide $(\mathrm{NaOH})$ to prevent acid attack. This greatly added to the mass of chemicals stored in the tanks. In addition, the reprocessing technology used at Hanford for the first ten years was the Bismuth Phosphate Process (BPP). While that process produced very high purity $\mathrm{Pu}$ for the first nuclear weapons ever produced, the BPP created one hundred times more waste per ton of Pu recovered than the PUREX Process, which later became the standard for DOE uranium $(\mathrm{U})$ and $\mathrm{Pu}$ as well as for commercial spent nuclear fuel reprocessing.

The result is that the Hanford tank wastes are far more chemically complex and heterogeneous than tank wastes at other DOE production sites. The Hanford tank wastes also tend to have substantially lower average radionuclide concentrations than other DOE tank wastes because of the inefficient recovery processes initially used (BPP), and the more than one hundred million curies of radionuclides [particularly cesium-137 $\left({ }^{137} \mathrm{Cs}\right)$ and strontium-90 $\left.\left({ }^{90} \mathrm{Sr}\right)\right]$ that were removed from the Hanford tanks forty years ago.

It is generally understood that the highly radioactive materials resulting from the reprocessing of spent nuclear fuel are HLW (NWPA 1983, Nuclear Waste Policy Act of 1983, Public Law 97- 
425; 96 Stat. 2201). Given the high cost and limited availability of potentially suitable deep geologic disposal sites for HLW, DOE recognizes that the high chemical content of the Hanford tank waste was unsuitable for total immobilization as vitrified HLW. Figure 1-2, which was derived from data in the Hanford Tank Waste Information Network System (TWINS) database, illustrates the relationships between the mass of radionuclides and the mass of chemicals that make up the Hanford tank wastes.

The pretreatment processes that will be carried out in the WTP pretreatment plant accomplish two key activities. First they separate the chemical wastes from the radioactive materials to the maximum extent practical to minimize the mass of wastes that will require vitrification as HLW. Second, by removing key radionuclides from the chemical waste fraction to the maximum extent technically and economically practical, the pretreatment processes should satisfy the first Waste Incidental to Reprocessing (WIR) criterion in DOE Manual 435.1-1,

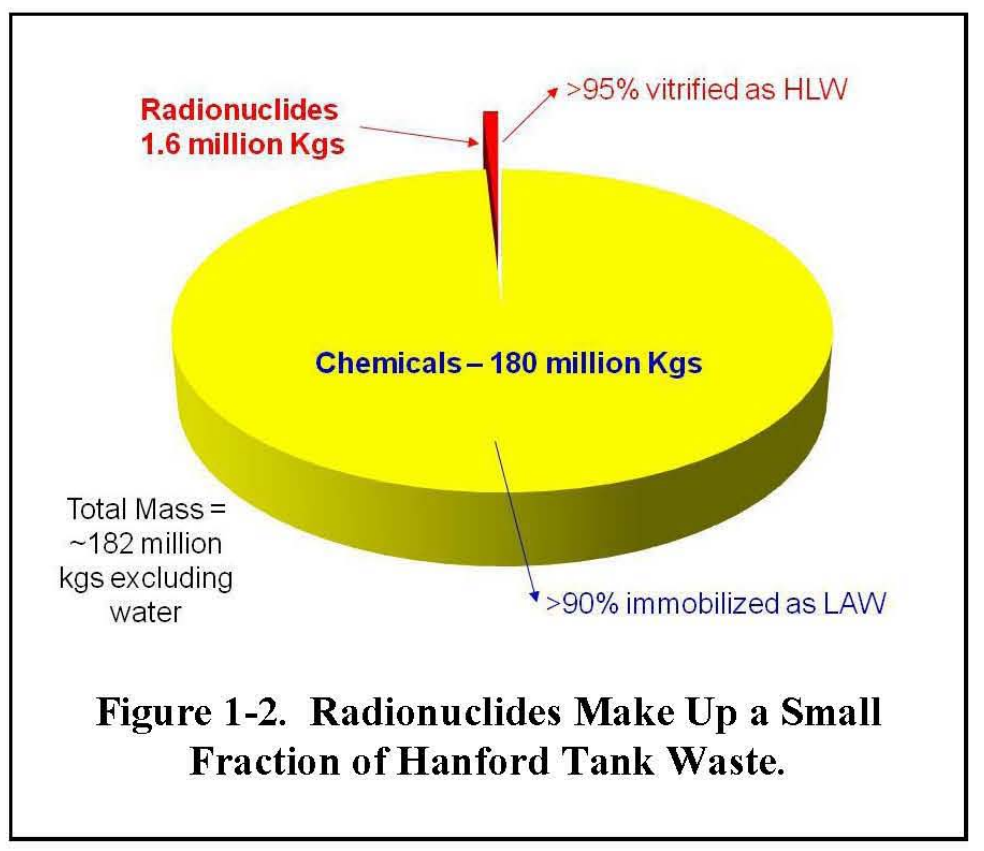

Radioactive Waste Management. The second factor is a critical element to classifying the LAW as non-HLW suitable for disposal on-site at Hanford. In addition to the chemicals in the tanks, substantial quantities of process sodium $(\mathrm{Na})$ will be added during the pretreatment of the tank wastes. The Hanford tanks contain approximately 48,000 metric tons (MT) of Na, essentially all of which will require immobilization as LAW. Additional process Na will be added during the waste pretreatment in the WTP.

The largest contributor to pretreatment $\mathrm{Na}$ additions will result from $\mathrm{NaOH}$ added to remove $\mathrm{Al}$ from HLW sludge waste during hot sludge leaching and the additional $\mathrm{NaOH}$ added to keep the aluminum (Al) in solution as the leachate is cooled from $80^{\circ}-90^{\circ}$ Celsius (leach temperature) to $25^{\circ}-45^{\circ}$ Celsius for processing through the cesium (Cs) ion exchange system. Because the LAW storage and treatment systems in the WTP pretreatment plant are not designed to handle solids (solids are separated and sent to the HLW storage and treatment systems), it is important that solids do not precipitate in those systems. For purposes of this report it is estimated that the total mass of $\mathrm{Na}$ that will require immobilization will be in the range of 65,000 to 70,000 MT.

\subsection{WHAT IS LOW-ACTIVITY WASTE?}

Low Activity Waste is the fraction of the tank wastes that is mostly chemicals and from which key radionuclides have been removed to the maximum extent technically and economically practical to render the waste not highly radioactive. The DOE will use a formal process to establish that the LAW waste produced through its planned pretreatment and immobilization processes is not HLW and is suitable for disposal on-site. The criteria used to make a 
determination $^{3}$ that the LAW is not HLW were developed in concert with the NRC (Bernero 1993) and the NRC will consult with DOE on its analyses showing that those criteria are met. The criteria are contained in DOE Manual 435.1-1, "Waste Incidental to Reprocessing (WIR) Requirements". The process by which the waste determination is made is called the WIR evaluation process. That process requires that DOE demonstrate that:

1. Waste is processed to remove key radionuclides ${ }^{4}$ to the maximum extent technically and economically practical,

2. If the treated and immobilized waste is disposed of by land disposal, that performance objectives comparable to those set forth in 10 CFR 61, Subpart C will be met, and

3. Waste is converted into a solid material with radionuclide concentrations that do not exceed 10 CFR 61.55 Class C concentration limits.

The resulting waste would be radioactively equivalent to LLW (i.e., no longer highly radioactive) and proven to be safe for disposal on-site. Given the derivation of the waste from tank wastes, DOE applies the term LAW to avoid confusion with wastes that are LLW at the point of generation. Because the Hanford tank wastes are regulated under the RCRA, LAW wastes are mixed LLW.

A two-step treatment approach removes the key radionuclides to the maximum extent technically and economically practical. The first step conducts solid and liquid separations on the liquid waste (supernatant) from the tanks to remove insoluble radionuclides such as transuranic isotopes and ${ }^{90} \mathrm{Sr}$. The second step performs $\mathrm{Cs}$ ion exchange on those wastes to remove ${ }^{137} \mathrm{Cs}$. The Hanford WTP implements this key radionuclide removal approach in the pretreatment plant. The plant produces the LAW liquid feed that will be converted to glass in the LAW melters. Figure 1-3 depicts the basic pretreatment concept to produce Hanford LAW feed from tank waste.

\footnotetext{
${ }^{3}$ The same criteria and process will also be applied to other tank waste related waste streams such as residuals remaining following the retrieval of wastes from tanks in accordance with TPA retrieval requirements.

${ }^{4}$ Key radionuclides generally refers to those radionuclides that if not removed would result in the most significant impacts to human health.
} 
RPP-49062, Rev 0

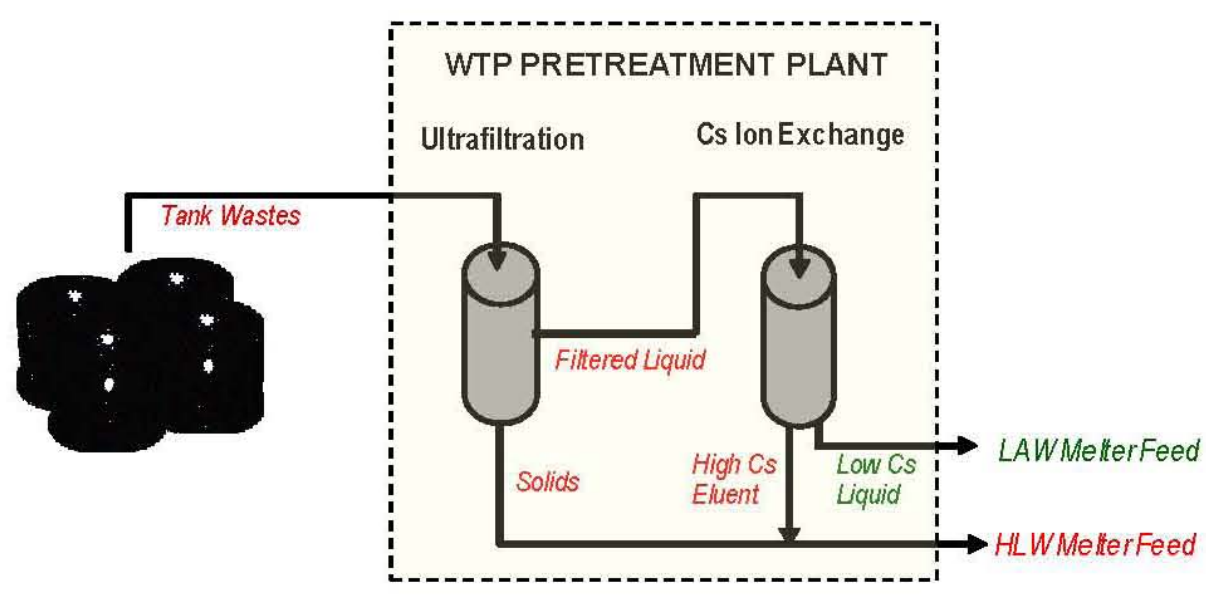

Figure 1-3. Depiction of Basic Pretreatment Processes to Remove Key Radionuclides from Hanford Tank Waste and Produce LAW Feed for Immobilization

While Figure 1-3 illustrates the WTP pretreatment processes currently under construction, DOE is also considering supplemental pretreatment approaches that would provide filtration and ion exchange pretreatment of LAW feed in the tank farms. This latter approach could potentially decrease the treatment mission duration by enabling the WTP pretreatment plant to primarily focus on the sludge pretreatment processes.

\subsection{WHY IS ADDITIONAL WTP LAW IMMOBILIZATION CAPACITY NECESSARY?}

The Hanford WTP Project was established in the 1990's. It was under a privatization concept wherein a private contractor would design, build, and operate the WTP using its own funding sources, i.e., no upfront federal funding. The contractor was to be paid on a unit basis as waste was successfully treated and immobilized.

Given project uncertainties and the high cost of building treatment facilities, a phased implementation approach was planned. The first phase would include a pretreatment facility, a HLW vitrification facility, and a LAW vitrification facility. The initial WTP would treat at least $10 \%$ of the tank waste mass containing at least $25 \%$ of the tank waste radioactivity during Phase I. Based on lessons learned during Phase I, the WTP would be upgraded to complete treatment and immobilization of the remaining tank wastes during Phase II.

The pretreatment plant was to be designed to process all of the tank waste over both mission phases, but would operate at a relatively low throughput capacity during Phase I. The HLW vitrification plant was designed to accommodate two melters, each processing 3 metric tons of glass per day (MTGD), however, only one 1.5 MTGD melter was to be initially installed and used for Phase I operations. The LAW vitrification plant was initially planned for three LAW melters, but the design was finalized for two LAW melters having a total net throughput capacity of net 30 MTGD, which was sufficient to handle all LAW generated during Phase I. The LAW immobilization throughput would need to be increased for Phase II to several times the throughput that could be provided by the first LAW plant. While economies of scale made it practical to design the Pretreatment and HLW vitrification facilities to accommodate the 
higher throughput required for Phase II, the same was not true for the LAW vitrification plant for two reasons.

The first was uncertainty regarding how much LAW immobilization capacity would actually be required to complete the overall treatment mission. One of the principal objectives of the WTP is to transfer as much non-radioactive waste mass as reasonable from the HLW fraction to the LAW fraction in order to minimize the amount of geologic repository space and disposal cost required to accommodate the $\mathrm{HLW}$. DOE was conducting studies to determine how much Al and other non-radioactive wastes could be leached from the HLW sludge from the tanks, as well as to determine how much non-waste, sodium hydroxide $(\mathrm{NaOH})$ would need to be added during pretreatment to reach its objectives. Whatever waste was leached from the HLW sludge and whatever $\mathrm{Na}$ needed to be added to the process to effect that removal was to be immobilized as LAW. Consequently, DOE did not know how large the LAW immobilization capacity would be during Phase II.

A second reason was uncertainty regarding whether LAW vitrification would prove to be the best immobilization solution for all of the LAW that would be generated. DOE and international entities in the United Kingdom and France had experience with the vitrification of HLW. Vitrification of LAW, however, was unique to Hanford. The Tank Waste Remediation System (TWRS) Environmental Impact Statement (EIS) Record of Decision (ROD) (62 FR 8693, Record of Decision for the Tank Waste Remediation System) left open the possibility other remediation approaches could result as information emerged during the conduct of the mission.

"The Phased Implementation alternative was selected because it provides a balance among short-and long-term environmental impacts, meets all regulatory requirements, addresses the technical uncertainties associated with remediation, and provides the flexibility necessary to accommodate future changes in the remediation plans in response to new information and technology development." [TWRS EIS ROD, DOE 1997]

\subsection{HOW WERE THE CANDIDATE LAW TECHNOLOGIES SELECTED?}

In 2002 and 2003 DOE initiated a series of meetings with Ecology and the U.S. Environmental Protection Agency (EPA) that were focused on determining whether an approach other than building a Second WTP LAW Vitrification Plant would best fill out the RPP flowsheet and, if so, what technologies should be considered ${ }^{5}$. Over the course of a year, a joint work group with representatives from each of those agencies and the Hanford Tank Farm Contractor reviewed several dozen potential technical approaches; four of which were evaluated in detail as the primary contenders for completing the LAW immobilization mission. Those four are the same as were listed earlier in the Introduction of this report, Second LAW Vitrification Plant, Bulk Vitrification, Cast Stone, and FBSR.

A procurement process was initiated to obtain design, cost, and waste form data for the latter three technologies. This was not considered necessary for the Second LAW Vitrification Plant

\footnotetext{
${ }^{5}$ The meetings were held as a subgroup of the Cleanup, Constraints, and Challenges Team (C3T), an informal forum where ideas and concepts could be discussed openly between DOE, EPA, and Ecology. Ideas were developed and evaluated to determine whether they could accelerate cleanup; reduce costs; or protect workers, the public, and the environment.
} 
RPP-49062, Rev 0

given the significant DOE investment in that technology and information available from the WTP Project.

On the basis of its meetings with the Washington Department of Ecology (Ecology) and EPA, DOE decided to further evaluate Bulk Vitrification at Hanford based primarily on a substantial cost advantage it appeared to have over a Second LAW Vitrification Plant and FBSR. DOE further decided that Idaho National Laboratory (INL) would conduct FBSR studies considering both INL sodium-bearing waste (SBW) and Hanford LAW. The SRS was already substantially invested in Saltstone, the SRS equivalent to Cast Stone, which SRS planned to use to immobilize its counterpart to Hanford LAW.

\subsection{REGULATORY REQUIREMENTS FOR ON-SITE DISPOSAL OF LAW}

There are six sets of regulatory requirements that must be met to dispose of immobilized LAW on-site at Hanford.

- RCRA Requirements, ( Resource Conservation and Recovery Act of 1976)

- TPA Requirements (DOE, 1989, Hanford Federal Facility Agreement and Consent Order - Tri-Party Agreement, (TPA),

- DOE Manual 435.1-1 Waste Incidental to Reprocessing (WIR) Requirements,

- DOE Manual 435.1-1 Disposal Authorization Requirements,

- Integrated Disposal Facility (IDF) IDF 2004, Integrated Disposal Facility Waste Acceptance Criteria, and

- IDF Permit Requirements. (IDF 2004 CEES-0134, Rev. B, Integrated Disposal Facility Waste Acceptance Criteria.)

Each is briefly discussed below.

\subsubsection{RCRA Requirements}

All Hanford tank waste is regulated under RCRA because of the hazardous constituents in the tank wastes. The hazardous (dangerous waste) constituents are also regulated under the Washington State Hazardous Waste Management Act and respective implementing regulations. The tank wastes carry RCRA codes D002 (corrosive), D004 (toxicity arsenic (As)), D005 (toxicity barium (Ba)), D006 (toxicity cadmium (Cd)), D007 (toxicity chromium (Cr)), D008 (toxicity Pb), D009 (toxicity mercury (Hg)), D010 (toxicity selenium (Se)), and D011 (toxicity silver (Ag)) for which the RCRA best demonstrated available technology (BDAT) is High Level Vitrification (HLVIT). In order to deploy a non HLW vitrification technology to treat the tank wastes DOE would need to submit a request for a Determination of Equivalent Treatment (DET) to the EPA for the alternative technology. The EPA would need to approve the DET before DOE could deploy the technology. The DET formally establishes the adequacy of the nonvitrification technology to treat the LAW and establish that the final waste product will meet RCRA LDR.

In addition, since DOE plans to base the contents of the immobilized waste on its analysis of what is in the waste feed rather than sample the contents of every immobilized waste package, DOE must also request Ecology to approve a Treatability Variance (TV) to enable that approach. This would be required regardless of the immobilization technology deployed. 
DOE must also obtain a RCRA permit to build and operate any facility to treat and immobilize the LAW regardless of the technology deployed.

\subsubsection{Tri-Party Requirements (TPA)}

The TPA (http://www.hanford.gov/?page=82) was signed in 1989 by Ecology, EPA and DOE with the purpose of coordinating the Comprehensive Environmental Response, Compensation, and Liability Act (CERCLA) and RCRA cleanup authorities at Hanford. The TPA also identifies specific cleanup milestones to be met; the process for changing, removing, or adding milestones; the conditions under which penalties may be issued; and the requirements for public involvement relating to Hanford cleanup actions. Major changes to the TPA require approval of all three agencies and are only made after a public participation process has been followed.

Appendix D to the TPA, Work Schedule and Designation of Lead Regulatory Authority, establishes key milestones for the processing and immobilization of the HLW and LAW from the Hanford tanks (M-062 milestone series). These include (paraphrased):

M-062-00 Complete all treatment and immobilization of tank wastes by December 31, 2047.

M-062-30 Complete negotiations establishing milestones for implementing near-term (2011 2016) actions related to LAW treatment and immobilization (October 2011).

M-062-40 Multipart milestone that includes requirement for DOE to submit a one-time Hanford Tank Waste Supplemental Treatment Technologies Report if a technology other than a $2^{\text {nd }}$ LAW vitrification facility is proposed.

M-062-45 Multipart milestone that includes requirement for a one-time supplemental LAW treatment selection consistent with M-062-00 including implementing supplemental treatment milestones (April 30, 2015).

M-062-49 Submit a report to Ecology with data certified to be accurate that demonstrates that the WTP is designed to accomplish at least the pretreatment of $100 \%$ of retrievable waste, vitrify $100 \%$ of HLW, and WTP LAW with supplemental treatment can immobilize $100 \%$ of LAW (October 31, 2011).

\subsubsection{DOE Manual 435.1-1 Waste Incidental to Reprocessing (WIR)}

Most of the waste in the Hanford tanks either originated during spent nuclear fuel reprocessing or has been subsequently comingled with reprocessing wastes. In order to manage and dispose of tank waste as other than HLW, DOE must determine the waste to not be HLW using either the citation or evaluation WIR process set forth in DOE Manual 435.1-1. The citation process is primarily applied to wastes that can be readily determined to not be HLW based on inspection, e.g., contaminated tools and clothing. The responsible DOE field element manager makes the process determinations.

Evaluation process WIR determinations are more complex. With evaluation process WIRs, treatment and analyses are required to render the waste not highly radioactive and then demonstrate that it is suitable for disposal in a LLW disposal site. Treatment (e.g., ultra or 
micro filtration and $\mathrm{Cs}$ ion exchange) is required to remove key radionuclides (typically

actinides, ${ }^{90} \mathrm{Sr}$, and ${ }^{137} \mathrm{Cs}$ ) to the maximum extent technically and economically practical. An engineering trade study is required to demonstrate that the degree of radionuclide removal will meet that objective. A performance assessment and other analyses are required to demonstrate that performance objectives comparable to those in 10 CFR Part 61, Subpart C will be met if the waste is disposed of by land disposal, e.g., in the Hanford IDF. Additional analyses are required to demonstrate that the immobilized waste will have radionuclide concentrations within those set forth in 10 CFR 61.55, Class C concentration limits.

Once the WIR analyses and supporting documentation are approved by DOE HQ, the draft WIR is published in the Federal Register and public comments are elicited. DOE also requests NRC staff consultation on the draft WIR and supporting documentation. This typically takes nine months or longer and involves NRC requests for additional information, DOE responses to those requests, and a NRC Technical Evaluation Report. Once the NRC and public input are integrated into the WIR as appropriate, the formal evaluation process WIR determination is made by the responsible DOE secretarial officer or designee.

\subsubsection{DOE Manual 435.1-1 Disposal Authorization}

In order for a waste to be disposed of in a DOE disposal facility such as the IDF, a formal disposal authorization must be in place that authorizes disposal. The disposal authorization is issued by an EM Deputy Assistant Secretary and is largely based on a recommendation from the Low-Level Waste Federal Review Group (LFRG) that the disposal facility is adequately protective of human health and the environment based on a Performance Assessment (PA) developed for that facility and contributing impacts from near-by facilities.

\subsubsection{IDF Waste Acceptance Criteria Requirement}

Waste acceptance criteria will be established for the IDF that places restrictions or requirements on wastes received at that facility for disposal in order to ensure that those wastes are properly characterized and documented by the waste generator relative to their origin, constituents, inventory, and characteristics or properties of the waste forms. The waste acceptance criteria is in part derived to be consistent with the waste types/inventories evaluated in the PA for the facility and in part based on engineering considerations such as compressive strength to protect against post-disposal surface subsidence.

At present, the IDF waste acceptance criteria exists in draft form (IDF 2004, CEES-0134, Rev. $\mathrm{B}$, Integrated Disposal Facility Waste Acceptance Criteria). The waste acceptance criteria will need to be finalized prior to waste acceptance for disposal in the IDF.

\subsubsection{IDF Permit Requirement}

Because the ILAW and related secondary waste to be disposed of in the IDF are derived from the Hanford tank waste, those wastes are regulated under RCRA and must meet RCRA LDR. Moreover, the IDF disposal cells that receive those wastes are subject to a RCRA permit issued by Ecology. The current IDF RCRA permit only covers ILAW glass from the WTP and up to 50 boxes of vitrified waste from Bulk Vitrification. The permit will need to be updated in order to receive secondary wastes from the tank farms and WTP as well as ILAW from other than a 
RPP-49062, Rev 0

Second WTP LAW Vitrification Facility. The permit update will in part be based on the results set forth in the IDF PA.

\subsection{DETERMINING WASTE FORM PERFORMANCE}

\subsubsection{Tests Used to Predict Long-Term Waste Form Performance}

A variety of tests are used to determine the long-term performance properties of candidate waste forms (waste form durability). Information derived from those tests is used to provide waste form performance input to the IDF PA analyses. The types of tests used depend, in part, upon the type of waste form. While ideally a waste form would hold radioactive and hazardous constituents permanently, that just is not practical to achieve. Rather, the purpose of a waste form is to retard the release of radioactive and hazardous constituents such that releases are at very low rates and extend over very long periods, such that impacts to human health and the environment are within levels allowed by environmental laws and regulations. Because the times over which releases can occur are typically measured in thousands, tens of thousands, or even millions of years for $100 \%$ release, the tests and analytical techniques used to measure waste form performance must rely on relatively short-term periods of measurements (days, months, or years) to make very long-term predictions.

Accordingly, scientists have devised ways to approximate the long-term corrosion of waste forms over the shorter time frames during which tests can be reasonably conducted using tests at higher temperatures and higher $\mathrm{pH}$ conditions, both of which accelerate the rate of attack well beyond what would occur in the Hanford vadose zone environment. Some waste forms, such as Cast Stone, release contaminants when water or contaminants move through the waste form by diffusion through the small pores within the waste form. Other waste forms such as glass and minerals suffer surface corrosion, are protected for some period of time by the corrosion product buildup on their surfaces, and then suffer corrosion again when the corrosion products are ultimately flushed or dissolved away. Determining the rates of releases for such waste forms requires batteries of complex tests and complex kinetic rate equations.

For glass and for mineral waste forms such as produced by the FBSR process, the tests are essentially the same due to similarities in the means by which those two waste forms eventually release contaminants to the vadose zone groundwater. In both cases kinetic rate equations are used to calculate the projected release rates, which can span millions of years. Cast stone uses some different test protocols that are focused on diffusion through the waste form over periods of thousands or tens of thousands of years. The applicability of the tests to various waste forms is shown in Table 1-1. A brief discussion of each test protocol ${ }^{6}$ is provided below.

\footnotetext{
${ }^{6}$ The Vapor Hydration Test (VHT), is not discussed because it was specifically developed for glass, has not yet been adequately demonstrated to the scientific community to provide information that correlates well to long-term performance (WSRC-STI-2008-00268), and is not well suited for surrogate testing.
} 
Table 1-1. Principal Waste Form Test Protocols

\begin{tabular}{|l|l|l|l|l|}
\hline Test Protocol & $\begin{array}{l}\text { WTP } \\
\text { LAW } \\
\text { Glass }\end{array}$ & $\begin{array}{l}\text { Bulk } \\
\text { Vitrification }\end{array}$ & $\begin{array}{l}\text { FBSR } \\
\text { Mineral }\end{array}$ & $\begin{array}{l}\text { Cast } \\
\text { Stone }\end{array}$ \\
\hline Toxicity Characteristic Leaching Procedure (TCLP) & $\checkmark$ & $\checkmark$ & $\checkmark$ & $\checkmark$ \\
\hline Product Consistency Test (PCT or ASTM C1285) & $\checkmark$ & $\checkmark$ & $\checkmark$ & \\
\hline Single Pass Flowthrough Test (SPFT or ASTM C1662) & $\checkmark$ & $\checkmark$ & $\checkmark$ & \\
\hline Pressurized Unsaturated Flow (PUF) test & $\checkmark$ & $\checkmark$ & $\checkmark$ & \\
\hline ASTM D6527, Hydraulic Conductivity in Porous Media & & & & $\checkmark$ \\
\hline ASTM/ANS 16.1, Leachability of Solidified LLW & & & & $\checkmark$ \\
\hline $\begin{array}{l}\text { ASTM C39/C 39M, Compressive Strength of Cylindrical } \\
\text { Concrete Specimens }\end{array}$ & & & $\checkmark^{7}$ & $\checkmark$ \\
\hline
\end{tabular}

TCLP-The EPA Test Method 1311, Toxicity Characteristic Leaching Procedure (TCLP) is designed to determine the mobility of both organic and inorganic analytes present in liquid, solid, and multiphasic wastes. This usually determines if a waste may meet the definition of EPA toxicity, that is, carrying a hazardous waste code under RCRA (40 CFR Part 261) of D004 through D052. The TCLP analysis simulates landfill conditions and determines which of the contaminants identified by the EPA are present in the leachate and the concentrations of such contaminants. For Hanford tank wastes, TCLP analysis will be used to determine whether the treated immobilized waste will meet RCRA LDR (42 USC 6901, Resource Conservation and Recovery Act, 40 CFR 268, and WAC 173-303, Washington State Dangerous Waste Regulations to be suitable for on-site disposal.

$P C T$ - The Product Consistency Test (PCT) was developed between 1987 and 1994 when it became an ASTM standard for HLW borosilicate glass (Jantzen 1994). In 1997 and 2002 the scope was broadened to include hazardous waste glasses, mixed waste glasses, and glass ceramics. Based on extensive testing of glasses and glass-ceramics, including a sevenlaboratory round robin, and confirmatory testing with radioactive samples, the PCT has been shown to be reproducible to distinguish between waste forms of different durability and homogeneity, to yield reliable results, and to be suitable for radioactive samples testing. Additional PCT testing of ceramic waste forms has occurred since 2002 and application of this test to ceramic waste forms is currently being considered by ASTM (WSRC-STI-2008-00268, "Mineralization of Radioactive Wastes by Fluidized Bed Steam Reforming (FBSR); Comparisons to Vitreous Waste Forms and Pertinent Durability Testing").

The PCT uses a granular waste form product typically between $>74 \mu \mathrm{m}$ and $<149 \mu \mathrm{m}$ at elevated temperature $\left(90^{\circ} \mathrm{C}\right)$ in de-ionized water at a solid-to-water ratio of $10 \mathrm{~g} / \mathrm{mL}$. The PCT

${ }^{7}$ Applied to waste form once in monolithic form. 
testing will be conducted using water solutions developed to represent burial conditions in the IDF, including natural vadose zone water chemistry and vadose zone water chemistry altered by groundwater attack on waste disposed of in the IDF. Ideally, PCT tests should be conducted over extended times (months to years) to better represent in situ weathering processes and to enable modeling of the weathered state of the waste form. The long-term PCT tests will be conducted consistent with ASTM C1285 - 02, 2008, "Standard Test Methods for Determining Chemical Durability of Nuclear, Hazardous, and Mixed Waste Glasses and Multiphase Glass Ceramics: The Product Consistency Test (PCT)".

SPFT - The SPFT test (ASTM C1662-10, Standard Practice for Measurement of the Glass Dissolution Rate Using the Single-Pass Flow-Through Test Method) is designed to measure reaction rates under tightly controlled, dilute solution conditions. Dissolution of silicate glasses or minerals in an aqueous solution is a dissociation-association process in which two or more soluble species are released into or removed from solution. It is subject to the common ion effect, which occurs when a solution already contains the same ions that would be released when a solid dissolves (or precipitates). The presence of common ions released from the glass or from other sources reduces the net rate of release relative to the rate in pure water. Hence, the idea of the SPFT test is to remove the elements released into solution from waste form dissolution by continuously introducing fresh water into the system. Run properly, the SPFT test provides a direct measure of the so-called "forward reaction rate." The forward reaction rate is the maximum rate at which a silicate glass or mineral can dissolve at a given temperature and $\mathrm{pH}$. Once the forward rate is known, it is straight forward to calculate the absolute upper bound on the release rate of any glass component, including a radionuclide such technetium $99\left({ }^{99} \mathrm{Tc}\right)$.

The SPFT test as a LAW product acceptance test is attractive for several reasons. First, the test provides a direct measure of the maximum possible corrosion rate of a glass or mineral that can be used in performance assessment analyses. Second, the test eliminates ambiguity that is unavoidable in interpreting the results from a closed-system test such as the PCT, where the solution $\mathrm{pH}$ and concentration of waste form components change as a function of time. The changing $\mathrm{pH}$ is particularly problematic because SPFT tests show that the forward reaction rate increases by approximately a factor of 3 for every unit increase in $\mathrm{pH}$ over the $\mathrm{pH}$ range from 7 to 12. Also, secondary phases can form in the PCT, which means that the solution concentration of some components may not give an accurate measure of the waste form corrosion rate.

Finally, because the PCT is a closed-system test, the results, particularly at early times and temperatures $<40^{\circ} \mathrm{C}$, are subject to phenomena such as ion-exchange, dissolution of fines, and reaction of highly strained fracture surfaces that are not true measures of the long-term, waste form dissolution rate.

$P U F$ - PUF tests (McGrail, Accelerated Testing of Waste Forms Using a Novel Pressurized Unsaturated Flow (PUF) Method) are important because they are conducted under hydraulically unsaturated conditions, which are the hydraulic conditions that exist in the vadose zone where the wastes will be ultimately disposed. PUF tests allow the corroding waste form to achieve its final reaction state in the most representative geochemical environment. Accordingly, PUF tests can provide insights into:

- Alteration phases that will form over time when the wastes are contacted by unsaturated groundwater, 


\section{RPP-49062, Rev 0}

- Time-phased changes in leachate (groundwater) chemistry resulting from waste form-groundwater interactions, and

- Waste form water reactions that occur under hydraulically unsaturated conditions similar to those expected in the Hanford disposal-system environment.

The PUF tests are conducted at elevated temperatures that accelerate the rate of attack on the waste form to enable predictions of long-term releases using tests conducted over months or years. Correlations will be developed between PUF test results and those obtained from the simpler (and less expensive) PCT tests and SPFT tests. PUF tests require the use of expensive equipment and protocols that limit the number of tests that can be performed with available equipment.

\section{American Society for Testing Materials (ASTM)}

ASTM D6527 - ASTM test method D6527, Test Method for Determining Unsaturated and Saturated Hydraulic Conductivity in Porous Media by Steady-State Centrifugation, is useful for measuring the hydraulic conductivity of grout-based waste forms. It is useful in measuring hydraulic conductivity in unsaturated disposal sites such as exists in the Hanford vadose zone.

ASTM C39/C39M - ASTM C39/C39M, Standard Test Method for Compressive Strength of Cylindrical Concrete Specimens, is a test used to determine the compressive strength of cylindrical concrete specimens such as molded cylinders and drilled cores with densities in excess of $50 \mathrm{lb} / \mathrm{ft}^{3}\left[800 \mathrm{~kg} / \mathrm{m}^{3}\right]$. The test protocols are also used for the FBSR monolithic waste form.

American National Standards Institute (ANSI) /American National Standards (ANS)

ANSI/ANS 16.1 - ANSI/ANS 16.1, Measurement of the Leachability of Solidified Low-Level Radioactive Waste, leaching procedure is used to determine the concentration and to calculate the leach rate for $\mathrm{Tc}, \mathrm{U}, \mathrm{I}$, nitrate, nitrite, $\mathrm{Cr}$, and $\mathrm{Cs}$. This standard provides a uniform procedure to measure and index the release of radionuclides from waste forms as a result of leaching in demineralized water for five days (seven data points). The results can be interpreted to apply to specific environmental situations through correlative studies of actual disposal site conditions.

\subsubsection{Performance Objectives Used to Evaluate Performance Assessment Results}

The ILAW waste form selected for use must be evaluated in the IDF PA and be shown to be protective of human health and the environment. The PA will evaluate the first 10,000 years following IDF closure and will also identify the time and magnitude of maximum doses if those peaks occur after 10,000 years. From a practical point of view, however, predictions of waste form performance and the fate and transport of long-lived radionuclides (such as ${ }^{99} \mathrm{Tc},{ }^{129} \mathrm{I}$, and ${ }^{238} \mathrm{U}$ ) over tens of thousands of years are subject to a number of uncertainties. These include those associated with using accelerated testing techniques to predict long-term waste form performance, as well as those associated with uncertainties regarding the chain of events assumed to occur in performance assessments. The latter are illustrated in Figure 1-4, which is adapted from RPP-15834, Revision 0, Integrated Disposal Facility Risk Assessment. As such, the performance assessment does not make a prediction of what will occur, but rather, tests the durability and robustness of the waste form and waste disposal system to perform acceptably 
given the variety of conditions (uncertainties) that could exist over the long time frames considered.

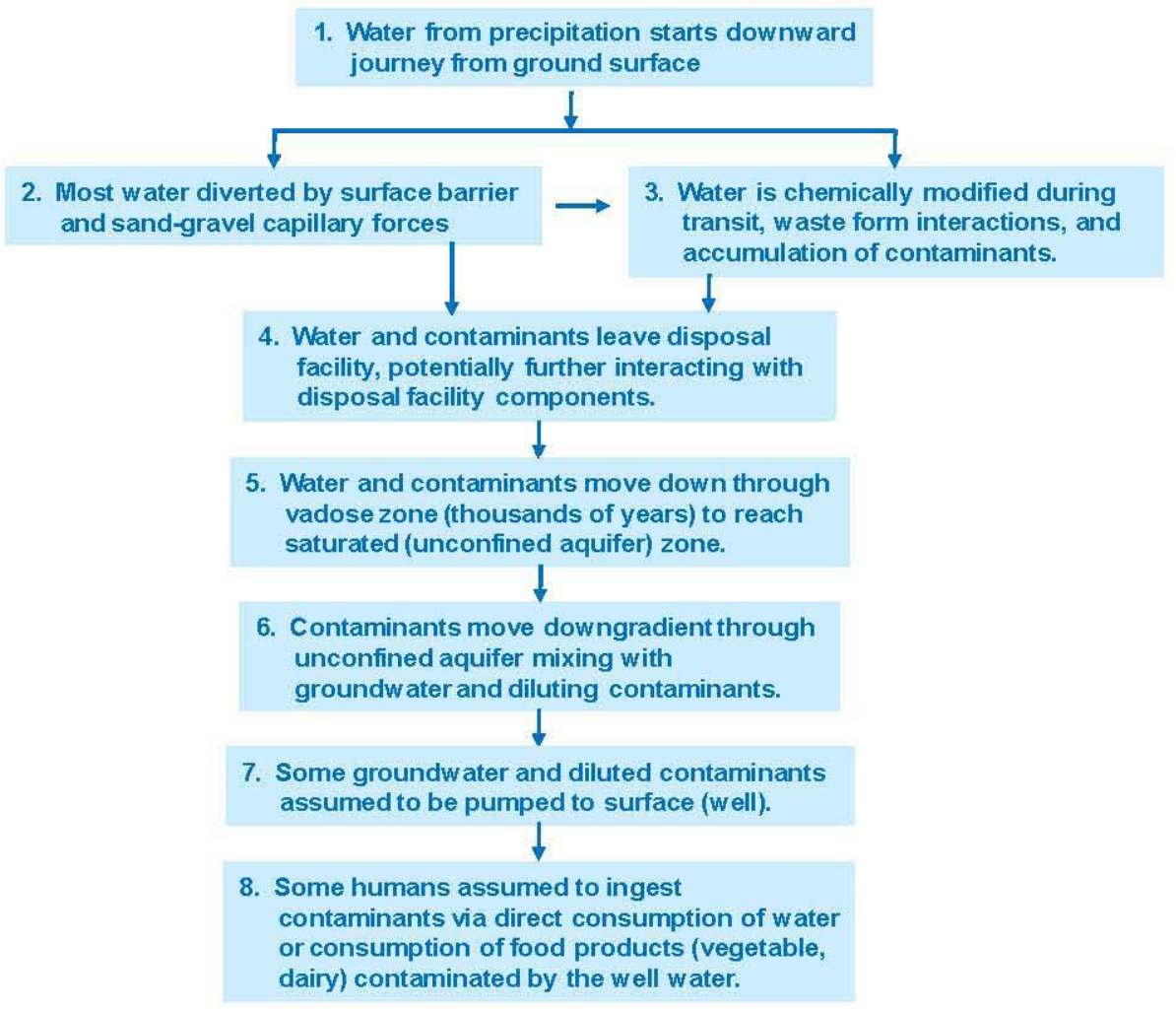

\section{Figure 1-4. Eight Steps Assumed in Performance Assessment Groundwater Pathway Models}

Such uncertainties include long-term climate changes that affect rainfall; long-term effectiveness of surface barriers that promote evaporation of precipitation over penetration into native soils; chemical reactions between the groundwater and soils and waste forms disposed of in the facility; influence of human-caused changes involving land use, technology, and current food chain-based predictive model applicability; and other currently unforeseen factors.

The PA analyses ultimately result in projections of doses to members of the public in close proximity to the disposal facility (e.g., drinking water or eating vegetables using water from a well adjacent to the disposal facility), lifetime cancer risks, and radionuclide concentrations; all of which are measured against established regulatory standards. The regulatory performance objectives or standards typically used are listed in Table 1-2 which was derived from RPP14283, Performance Objectives for Tank Farm Closure Performance Assessments. 
Table 1-2. Key Performance Objectives for Performance Assessment

\begin{tabular}{|c|c|}
\hline \multicolumn{2}{|c|}{ Protection of General Public and Workers ${ }^{a, b}$} \\
\hline $\begin{array}{l}\text { All-pathways dose from only this facility } \\
\text { All-pathways dose including other Hanford Site sources } \\
\text { Chemical Carcinogens (Incremental Lifetime Cancer Risk) } \\
\text { Non cancer-cause chemicals (hazard index) }\end{array}$ & $\begin{array}{l}25 \mathrm{mrem}^{\text {in a year }}{ }^{\mathrm{c}, \mathrm{d}} \\
100 \mathrm{mrem}^{\mathrm{m}} \text { in a year } \\
10^{-5} \mathrm{c}, \mathrm{d} \\
1^{\mathrm{c}, \mathrm{f}}\end{array}$ \\
\hline \multicolumn{2}{|c|}{ Protection of an Inadvertent Intruder ${ }^{\mathrm{a}, \mathrm{g}, \mathrm{h}}$} \\
\hline Acute and Chronic exposure & 500 mrem \\
\hline \multicolumn{2}{|c|}{ Protection of Groundwater Resources ${ }^{a, b, e, i}$} \\
\hline \multicolumn{2}{|l|}{ Alpha emitters } \\
\hline${ }^{226}$ Ra plus ${ }^{228} \mathrm{Ra}$ & $5 \mathrm{pCi} / \mathrm{R}$ \\
\hline All others (excluding U) & $15 \mathrm{pCi} / \mathrm{R}$ \\
\hline $\mathrm{U} 30 \mu \mathrm{g} / \mathrm{R}$ & $30 \mu \mathrm{g} / \mathrm{R}$ \\
\hline Beta and photon emitters & $4 \mathrm{mrem}$ in a year \\
\hline \multicolumn{2}{|c|}{ Protection of Surface Water Resources ${ }^{a, b, j}$} \\
\hline \multicolumn{2}{|l|}{ Alpha emitters } \\
\hline${ }^{226}$ Ra plus ${ }^{228} \mathrm{Ra}$ & $0.3 \mathrm{pCi} / \mathrm{R}^{\mathrm{i}}$ \\
\hline All others (excluding U) & $15 \mathrm{pCi} / \mathrm{R}^{\mathrm{i}}$ \\
\hline Beta and photon emitters & 1 mrem in a year ${ }^{\mathrm{k}}$ \\
\hline \multicolumn{2}{|c|}{ Protection of Air Resource ${ }^{b, h, 1}$} \\
\hline $\begin{array}{l}\text { Radon (flux through surface) } \\
\text { All other radionuclides }\end{array}$ & $\begin{array}{l}20 \mathrm{pCi} \mathrm{m}^{-2} \mathrm{~s}^{-1} \\
10 \mathrm{mrem}^{-1} \text { a year }\end{array}$ \\
\hline \multicolumn{2}{|c|}{$\begin{array}{l}\text { Notes: } \\
\text { all doses are calculated as effective dose equivalents; all concentrations are in water taken from a well. } \\
\text { Values given are in addition to any existing amounts or background. } \\
{ }^{\mathrm{b}} \text { Evaluated for } 1,000 \text { years, but calculated to the time of peak or } 10,000 \text { years, whichever is longer. } \\
{ }^{\mathrm{c}} \text { Evaluated at the point of maximal exposure, but no closer than } 100 \text { meters ( } 328 \text { feet) from the disposal } \\
\text { facility. Also calculated } 1 \text { kilometer from the facility and just before groundwater enters the Columbia River. } \\
{ }^{\mathrm{d}} \text { Main driver is DOE Orders on Radioactive Waste Management (DOE 1999a). } \\
{ }^{\mathrm{e}} \text { Evaluated } 100 \text { meters down gradient from IDF cell, which is assumed to be IDF site boundary. } \\
{ }^{\mathrm{f}} \text { Main benchmark is Washington State Model Toxics Control Act (WAC 173-340) as applicable. } \\
{ }^{\mathrm{g}} \text { Evaluated for } 500 \text { years, but calculated from } 100 \text { to } 1,000 \text { years. } \\
{ }^{\mathrm{h}} \text { Evaluated at the disposal facility. } \\
{ }^{\mathrm{I}} \text { Main benchmark is National Primary Drinking Water Regulations (40 CFR 141) as applicable. } \\
{ }^{\mathrm{j}} \text { Evaluated at the Columbia River, no mixing with the river is assumed. } \\
\left.{ }^{\mathrm{k}} \text { Main benchmark is Washington State Surface Water Standards (WAC } 173-201 \mathrm{~A}\right) \text { as applicable. } \\
{ }^{1} \text { Main driver is National Emission Standards for Hazardous Air Pollutants (40 CFR 61H and 40 CFR 61Q). }\end{array}$} \\
\hline
\end{tabular}




\subsection{DESIRED ATTRIBUTES OF SELECTED TECHNOLOGIES}

Any technology selected to immobilize Hanford LAW should have the following attributes:

- RCRA Compliant: Can be demonstrated to perform on an equivalent level to HLVIT standards under RCRA such that EPA DET approval is likely.

- Robust treatment: Ability to treat and immobilize the spectrum of LAW chemical and radioactive constituents anticipated to be in LAW feed.

- Operationally Stable: Minimal need for operator adjustments to system during operations for any given batch of feed.

- Predictable: Waste form performance characteristics can be adequately correlated to feed chemistry to support a Treatability Variance.

- Safe: Operationally reliable, stable, and predictable such that risks to operators, the public, and the environment are minimized.

- Durable waste form: Waste form controls release of radioactive and hazardous constituents to sufficiently low levels over sufficiently long time frames that projected impacts to human health and the environment are within applicable environmental regulatory standards.

- Cost Effective: Offers best value (capital and lifecycle costs) to the government considering whether the levels of performance, assurance, benefits, and risks inherent in the other parameters are listed above.

The remainder of this report is focused on the Cast Stone technology and why it is being considered for use at Hanford for the treatment and immobilization of LAW. 
RPP-49062, Rev 0

\subsection{INTRODUCTION TO CAST STONE TECHNOLOGY}

\subsection{WHAT IS CAST STONE TECHNOLOGY?}

Cast stone technology in different forms, has been used for centuries and continues to find applications in building, industry, garden ornamentation, and even sculptural restoration and preservation. The Cast Stone process has been applied to industrial waste handling in a number of technologies and more specifically at various nuclear facilities. Cast stone is a grout-based, solidification technology that receives waste streams (treated LAW in the case of Hanford) and produces a containerized, cement-based waste form that meets the waste acceptance criteria for the IDF. Cast stone technology is a variation of the cement-based, grout technology previously studied at Hanford with different waste formulations and preparation methods to allow the increased capture of ${ }^{99} \mathrm{Tc}$.

\subsection{WHY IS CAST STONE BEING EVALUATED FOR POSSIBLE USE AT HANFORD?}

The Cast Stone technology is being considered for possible use at Hanford because Cast Stone is routinely and reliably used around the world to treat various low-level radioactive and hazardous waste streams. It is considered a relatively simple treatment process and offers a variety of potential benefits compared to more complex thermal treatment processes.

Generally speaking, an immobilization technology such as Cast Stone is being considered for potential application in an immobilization facility because the WTP LAW capacity will not be able to process the entire waste inventory from the Hanford tank farms. The immobilization facility will solidify LAW that exceeds the WTP LAW facility capacity. As currently sized, the immobilization facility will immobilize the LAW feed from the WTP pretreatment facility and the treatment facility, which is more than half of the total LAW feed from the Hanford tank farms.

\subsection{HOW DOES THE CAST STONE PROCESS WORK?}

The solidification process using Cast Stone technology receives LAW in the form of pretreated dissolved saltcake with a nominal Na concentration of 5 Molar (M) and a range of $4 \mathrm{M}$ Na to 10 $\mathrm{M} \mathrm{Na}$. The nominal waste loading is expected to be on the order of $18-19 \mathrm{wt} \%$ waste solids per unit mass of Cast Stone ILAW, which equates to about $8 \mathrm{wt} \%$ on a $\mathrm{Na}$ oxide $\left(\mathrm{Na}_{2} \mathrm{O}\right)$ basis. The LAW is immobilized to produce ILAW in a Cast Stone product that meets specific waste form requirements suitable for onsite disposal. The following capacity estimates applicable to Cast Stone technology, are documented in RPP-CALC-48104, 2010, 200 Area Supplemental Treatment and Immobilization System Capacity.

- $\quad$ Supplemental treatment delivers 3,700 MT of Na per year at 70\% total operating efficiency (TOE) to supplemental immobilization. A factor of $70 \%$ efficiency is applied to the final calculated production rates of the facilities. This is the assumed TOE of the WTP as outlined in ORP-11242, River Protection Project System Plan, Rev. 5.

- The necessary supplemental immobilization facility has an approximate processing capacity of 2,600 MT of Na per year. 


\subsubsection{Feed Preparation Requirements}

The best formulation developed to-date for Cast Stone waste form comprises $8 \%$ Portland cement, $45 \%$ fly ash (Type F), and $47 \%$ blast furnace slag (Grade 120). If Cast Stone is selected for further evaluation, additional work will be needed to address the variability in LAW feed from the Hanford tank farms and the uncertainties related to retention of ${ }^{99} \mathrm{Tc}$ in the Cast Stone waste form. 


\subsubsection{Immobilization Process Overview}

Figure 5 provides a simple schematic of a potential Cast Stone Process System, which defines the primary processing steps and functions of the overall process operation from receipt of the pretreated LAW through conversion to an acceptable ILAW waste form. The process consists of a feed receipt, preparation, and feeding system; mixing and casting system; and container processing and handling system. Pretreated waste feed is evaporated to remove a portion of the water and then cooled to $25^{\circ} \mathrm{C}$ in a holding tank, from which it is fed to the mixing and casting system. The cement ingredients are staged in individual weighing tanks. The liquid LAW is pumped to the mixers, while the cement ingredients are fed using auger conveyors and gravity from weighing tanks above the mixers. Once mixed, the waste is poured into a waste container located below the mixer, which is later moved to the IDF.

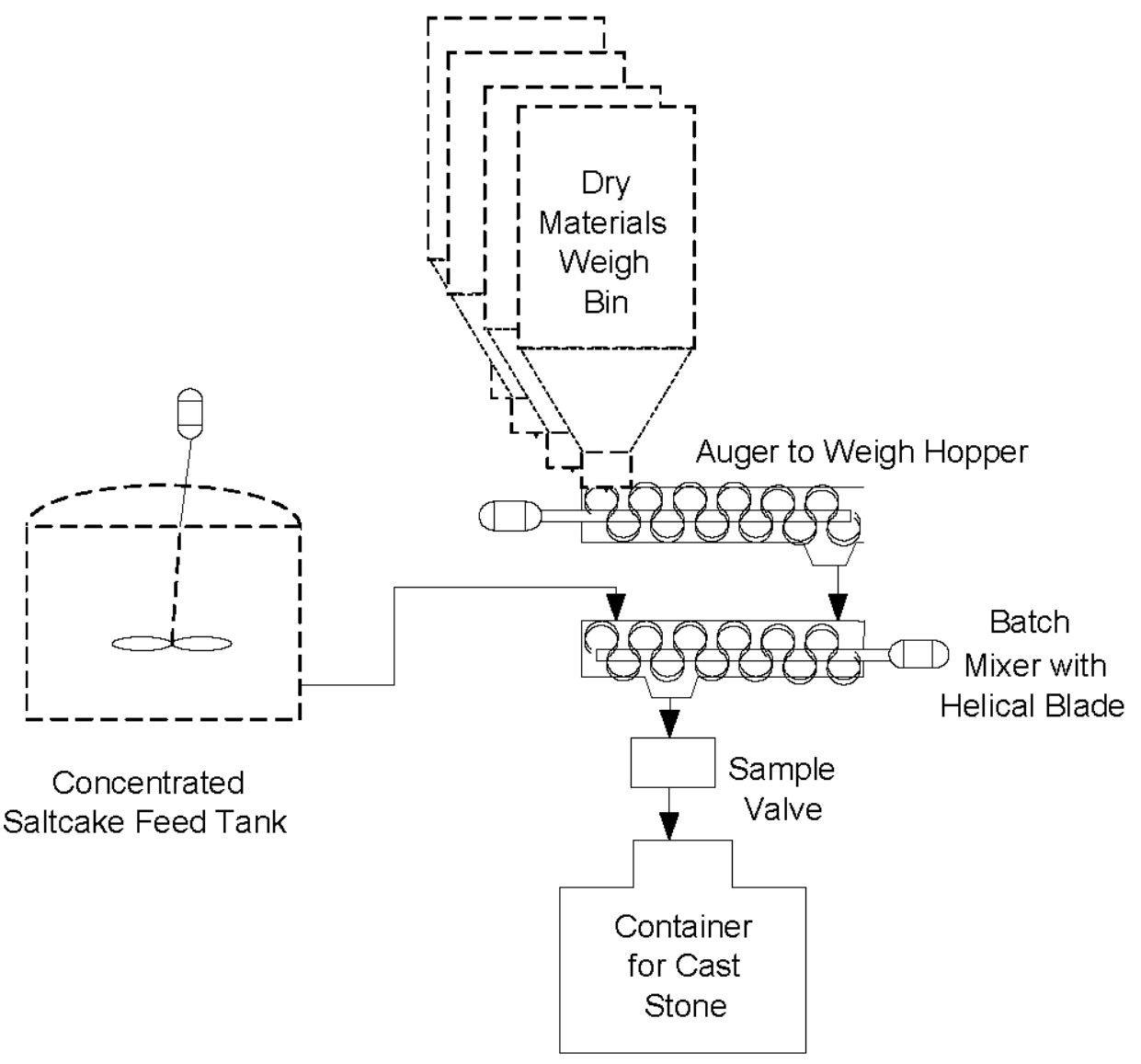

Figure 2-1. Schematic of Potential Cast Stone Process System (RPP-RPT-48092, Figure 4-25) 


\subsubsection{Waste Form Description}

For the purposes of this introductory report, the Cast Stone waste form is assumed identical to that specified in RPP-RPT-26689. Cast stone processes incorporate the hazardous and radioactive constituents of the waste into a monolithic solid to reduce mobility of the constituents of concern. Cast stone is a cement-based, monolithic waste form produced by blending Portland cement and chemical additives with LAW and is a variation of the cementbased grout technology with different waste formulations and preparation methods to allow the increased capture of ${ }^{99} \mathrm{Tc}$. Process of solidification chemically incorporates the stabilized constituents of concern into a monolithic solid matrix of high structural integrity.

\subsubsection{Off-gas Treatment}

Off-gas treatment of particulate filtration, off-gas radiological, and environmental monitoring are performed prior to the stack discharge of treated gases. The off-gas treatment system maintains radioactive contamination confinement by collecting the equipment off-gases and passing them through electric heater and High Efficiency Particulate Air (HEPA) filtration units before discharging through blowers to the stack via the facility Heating, Ventilation, and Air Conditioning (HVAC) control system.

\subsubsection{Ancillary Processes}

Features of the ancillary process systems and their uses include:

- Flush water, instrument plant or air supply, process-chilled water; stack gas monitoring, vacuum air sampling, non-radioactive or non-hazardous liquid effluents, sanitary liquid effluents, and standby power generation process systems.

- Instrument or plant air system that supports dense phase conveying, pneumatic process instruments, and air-operated valves, as well as providing a source of plant air for pneumatic tools used during maintenance.

- Process chilled water system that cools the concentrated LAW after the evaporation process and before mixing with dry reagents, because the Cast Stone product quality is temperature-dependent on the peak temperature attained during curing.

- Stack gas filtration and monitoring ensures particulate emissions discharged from the plant are minimized and air quality standards are met.

- Nonradioactive, non-hazardous liquid effluents are monitored and disposed of by the simplest and most cost-effective method to meet the waste acceptance criteria. 
RPP-49062, Rev 0

\subsection{PREVIOUS RELEVANT TESTS AND DEVELOPMENT HISTORY}

Cementitious materials have been used at multiple DOE locations for the solidification and disposal of low-level radioactive wastes. Oak Ridge National Laboratory (ORNL) began disposing of low-level liquid wastes in 1966 using a process known as hydraulic fracturing. This process involved mixing liquid low-level waste with a blend of cement, fly ash, pottery clay, and attapulgite clay, and pumping the slurry into shale formations underlying the ORNL site, causing the shale to fracture, and the grout to fill the resultant fissures.

\subsection{OVERVIEW OF PREVIOUS RELEVANT TESTS AND DEVELOPMENT HISTORY}

\section{$\underline{\text { Savannah River Site }}$}

The Savannah River Site (SRS) is using the Saltstone process in which the waste product is prepared by mixing the salt solution with a blend of fly ash, blast furnace slag, and cement. This process is similar to the grouting process used at the Hanford Site in 1980's and 1990's. At Hanford a major program was carried out in the late 1980's and early 1990's that culminated in a full-scale test to produce over one million gallons of low-level radioactive waste grout. As part of this program, a series of pilot scale tests and laboratory waste formulation studies were carried out to develop formulations for immobilizing LAW.

$\underline{\text { West Valley Disposal Plant }}$

Cement-based, radioactive waste immobilization systems have been and are being used worldwide. West Valley Disposal Plant (WVDP) has used these types of systems to immobilize caustic radioactive waste streams similar to the Hanford Site LAW.

Oakridge National Laboratory

The cement- based immobilization system was used at Oakridge National Laboratory in 2005 to immobilize uranium byproduct waste. Workers used remotely control machines to mix the uranium byproduct waste with fly ash, consisting of fine particles of ashes, dust and soot, and cement to create a loose grout. The loose grout mixture was mechanically poured through a chute into half-inch thick cylindrical carbon steel canisters. The solidified containers were lifted by an overhead crane and placed on specially designed flatbed trucks for shipment to designated waste disposal sites.

\section{Saltstone Facility, SRS}

The cement-based technology has been demonstrated in a relevant full-scale environment at the Saltstone Facility at SRS, with environments similar to the proposed application at the Hanford Site. The Saltstone process is similar to the grout process as described below. The Saltstone Facility started radioactive operations in 1990. Since that time and until recently the facility has been operated on an intermittent, as-needed basis to immobilize and dispose of low-activity liquid waste from the SRS Effluent Treatment Project, which processes waste from SRS's two chemical separation facilities, as well as from the tank farms.

Recently, in 2007 , operations were resumed with over 100,000 gallons of low-activity salt solution safely mixed with cementitious materials (cement, fly ash, and slag) and poured as a 
RPP-49062, Rev 0

concrete-like mixture into large vaults for permanent disposition at Saltstone. Since 2007, over 3.5 million gallons of salt waste have been processed and over 35 million gallons of salt waste is expected to be processed by 2017.

$\underline{\text { Hanford }}$

In 1987, the DOE constructed a grout processing facility at Hanford and processed over a million gallons of N-reactor clean-out solution (high phosphate or sulfate) waste, which was low-level waste, but not Hanford LAW. The processed waste was grouted as a monolith in a single vault, which was subsequently closed. For the past two decades the DOE at Hanford focused on immobilizing the low-activity fraction of the tank waste using vitrification. However, starting in the 1980 's, grout was initially thought to be the solution and several large grout vaults were constructed for that purpose.

Grout was abandoned shortly thereafter on the basis of analyses indicating that:

1. Vitrification costs no more than using grout when the total lifecycle treatment and disposal costs were taken in to account,

2. Costs were considered to be similar especially if a thermal process was necessary for Cast Stone to destroy organic or listed waste constituents,

3. Glass would better protect human health and the environment from long-lived radionuclides such as ${ }^{99} \mathrm{Tc}$ and iodine $129\left({ }^{129} \mathrm{I}\right)$ due to its long-term stability (e.g., very slow release of radionuclides over very long time frames, and

4. Volume of grout would be double or more than glass due to the lower waste loading thus increasing disposal costs.

At Hanford, Cast Stone technology was conceptualized to address a mission acceleration initiative in 2002 for tank waste treatment, which resulted in laboratory-scale testing. In 2005, a pre-conceptual design was completed to enable planning for prospective treatment options, RPPRPT-26689. Cement-based solidification studies were initiated in 2004 for Hanford Effluent Treatment Facility (ETF) evaporator waste streams. All tests were laboratory-scale product evaluations.

\subsection{PREVIOUS USES OUTSIDE THE DOE COMPLEX}

In the commercial nuclear industry, low-level waste ranges from trash suspected of being slightly contaminated to highly radioactive material such as activated structural components found within or in close proximity to the reactor are treated with grout. Grout is also sometimes used to treat reactor components, tools, condenser tubes and other miscellaneous contaminated wastes. Some low-level wastes generated in the commercial nuclear industry are not grouted, but placed in drums or containers for storage on-site and later shipped to licensed low-level waste disposal sites for direct disposal. 


\subsection{CURRENT STATE OF KNOWLEDGE USING CAST STONE TECHNOLOGY FOR HANFORD LAW}

\subsection{HOW CAST STONE MIGHT FIT INTO THE HANFORD TANK WASTE TREATMENT FLOW SHEET}

The Cast Stone technology will fit into the Hanford tank waste treatment flow sheet between the steps on the flowsheet shown in Figure 1. One unit is required to perform the immobilization function. The Cast Stone technology will lend itself to partitioning capacity into smaller facilities should that be desired.

In 2003, a pre-conceptual container Cast Stone design was prepared, RPP-RPT-26689. The process flow diagram of the Cast Stone process as shown in Figure 4-1 and the process system descriptions are excerpted from RPP-RPT-46668. 


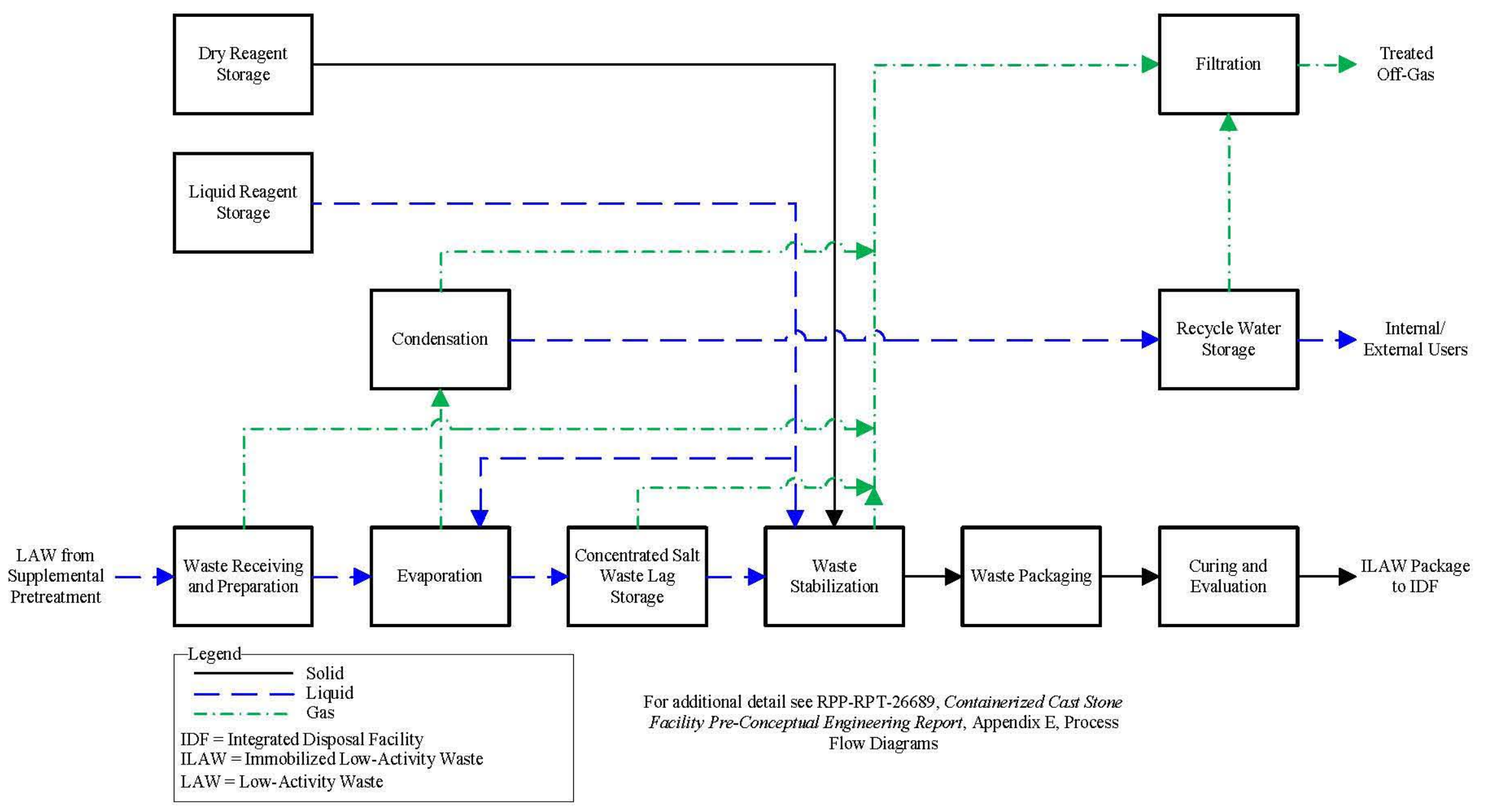

Figure 4-1. Process Flow Diagram for Containerized Cast Stone

(RPP-RPT-46668, Figure 6-16) 
The process flow diagram for Cast Stone as shown above is discussed in the process system descriptions below:

- Dry reagent receipt, storage, and metering - The three principal dry reagents are received in bulk shipments. Transport trucks equipped with self-contained blowers unload the reagents into the storage silos under the supervision of plant operators. The ferrous sulfate monohydrate is received and stored in super sacks that do not require a silo. The four dry reagents are transferred to their respective weigh bins via the dedicated dense-phase transfer systems. The plant control system controls the addition of dry reagents to each mixer batch by monitoring the weight lost from each reagent weigh bin as the respective contents are gravity-fed to the mixer by the screw conveyor.

- Liquid reagent receipt, storage, and metering - Limited quantities of liquid reagents are used in the containerized Cast Stone process. Where necessary, additives such as surfactants, plasticizers, or anti-foaming agents are procured and used in carboys or drums. Liquid reagents are added to the process stream via portable metering pumps. No dedicated storage tanks, pumps, or other permanent facility equipment or structures are needed to support liquid reagent usage.

- LAW feed evaporation - The evaporation system concentrates the as-received LAW feed to approximately $10 \mathrm{M}$ Na to attain the target waste loading of $18.8 \mathrm{wt} \%$ waste solids in the Cast Stone. The evaporation process control system automatically adjusts the evaporation process parameters (feed rate, heat input, and bottoms density as an indicator of Na molarity) to maintain the target $10 \mathrm{M}$ $\mathrm{Na}$ output concentration. Concentrated LAW is drawn off the evaporator bottoms to the concentrated saltcake storage tanks via the evaporator bottoms feed pumps. The evaporator design accommodates concentration of the most dilute anticipated LAW feed ( $4 \mathrm{M} \mathrm{Na}$ ) to $10 \mathrm{M} \mathrm{Na}$ at a rate sufficient to maintain the targeted average plant throughput. The evaporation processing step provides volume reduction of the LAW to achieve optimum waste loading in the Cast Stone waste form.

- Concentrated LAW feed storage - The concentrated LAW feed storage system provides cooling capacity and lag storage for the evaporator bottoms, allows monitoring of the solution density as an indicator of Na concentration, and feeds the concentrated LAW in homogeneous batches to the mixers. Homogenization of the concentrated LAW minimizes the occurrence of crystallization. The concentrated saltcake feed tank coolers reduce the temperature of the concentrated LAW before being fed to the mixers, which prevents overheating of the Cast Stone mixture during curing, thereby ensuring consistently high ILAW product quality.

- Evaporator condensate/recycle water - Evaporator condensate drains by gravity from the evaporator overhead condenser into the recycle water tanks. The recycled water is used for flushing the mixers at the end of the processing day to remove residual Cast Stone, and for tank and process line flushes to reduce 
localized radiation dose rates prior to equipment maintenance. Unused condensate (recycle water) is transferred to the Liquid Effluent Treatment Facility (LERF) basins for subsequent treatment at the ETF after sampling and characterization to verify LERF or ETF acceptance criteria have been confirmed.

- LAW stabilization - The LAW stabilization process chemically converts the hazardous and radioactive constituents of the waste into their least soluble, mobile, or toxic forms. Solidification chemically incorporates the stabilized constituents into a monolithic solid of high structural integrity. The mixer receives batches of concentrated LAW from the concentrated saltcake feed tanks and dry reagents from the dry reagent receipt, storage, and metering system. The dry reagents are gravity fed to the mixer from their respective weigh bins during the Cast Stone mixing period. Mixing requires a small batch, after which the mixer gravity drains the stabilized waste into an empty waste container staged in place by the ILAW containerization process. The mixer overhead pre-filters collect dust generated during dry reagent receipt and minimize the particulate load on the vessel vent system. The dust is processed and routed to the HVAC filtration system before discharge into the atmosphere.

- Vessel vent system - All vessels, the evaporator condenser, the Cast Stone mixers, and radiological confinement ventilation at the container fill stations are connected to the vessel vent system. The dry reagent weigh bins, located above the mixers, have pre-filters to minimize dust loading downstream in the vessel vent system. The vessel vent system uses redundant HEPA filtration and exhaust gas preheating to prevent condensation in the filters. The vessel vent system design maintains a negative pressure to draw process off-gas and particulate emissions from process equipment throughout the plant, including the saltcake storage and feed tanks, the mixers, the evaporator, the dry reagent weigh bins, and the recycle water tank. The air then passes through a heater followed by HEPA filtration to remove $99.97 \%$ of all particulates $0.3 \mu$ and larger. The filtered air then is exhausted to the HVAC system. Spent HEPA filters are disposed of in accordance with Hanford Site regulations.

- Waste packaging - The automated mechanical transfer systems stage empty waste containers beneath each of the mixers. With a container in place, the mixer unloading device is activated to provide a leak-tight conduit between the bottom of the mixer and the filling flange of the waste container. When batch mixing is complete, the mixer dump valve opens and the wet Cast Stone batch flows by gravity into the container. The mixer unloading device provides for the escape of displaced air from the container as the wet Cast Stone batch fills the container. The air flows through the mixer body to the vessel vent system. The displaced air is then routed to the ventilation system for HEPA filtration prior to discharge into the atmosphere. Following container closure, the automated mechanical transfer system advances the container to the radiological survey and decontamination area. The radiological survey and decontamination area is designed to allow all surfaces of the container to be surveyed. Operators and health physics technician's survey and decontaminate the sealed container as necessary at this location. Decontamination aids and the As Low As Reasonably Achievable 
(ALARA) principles of time, distance, and shielding are employed to minimize operator dose during the radiological survey and decontamination step. When the container has been determined to be below radiological contamination acceptance limits for transportation and disposal, a crane moves the container to the ILAW staging area location within the plant.

- ILAW staging area, curing, and evaluation - Container staging consists of retaining the filled and sealed ILAW Cast Stone containers in the indoor ILAW staging area of the facility for a week, after which the containers are transported to the outdoor covered loadout area. The staging period allows the Cast Stone to progress through the initial curing process, during which the majority of the hydration chemical reactions and accompanying heat release occurs. The container staging configuration is arranged to facilitate organized container storage and movement by crane, and to provide adequate natural convection transfer of Cast Stone curing heat away from the containers. Containers are tracked using labels and bar codes. During solidification facility operations, solidified waste product quality is evaluated by sampling the wet Cast Stone mix during the pour into the containers, and by monitoring the samples through the initial curing process. Characteristic samples of the solidified waste batches are taken from a remote sampling port between the upper and lower mixer unloading valves. The evaluation philosophy uses parallel characteristic sampling to evaluate quality of the solidified waste batches. Radiation dose rates in the ILAW staging area are elevated when the area is filled with containers. Therefore, operator presence in this area is minimized and surveillance is primarily conducted from the control room via closed-circuit television camera. The crane operating station is shielded to minimize dose to the crane operator. At the end of the staging period, containers ready for shipment are transported by crane to the exit decontamination station. A final radiological survey, and decontamination if necessary, is performed. The containers then proceed through the exit airlock via conveyor to the outdoor covered staging area to await loadout.

\subsection{TECHNOLOGY MATURITY}

This section discusses the process for establishing Technology Readiness Assessment (TRA), which is a snapshot in time of the maturity of Cast Stone technology and its readiness for insertion into the project design and execution schedule were it to be selected as the immobilization technology. The TRA evaluates technology maturity using the Technology Readiness Level (TRL) scale.

The TRA is an evaluation of how far technology development has proceeded for a specified system. A TRA measures technology maturity using the TRL scale that ranges from 1 (basic principles observed) through 9 (total system used successfully in project operations). The integration of the TRA process and critical decision (CD) is shown in Figure 4-2. 


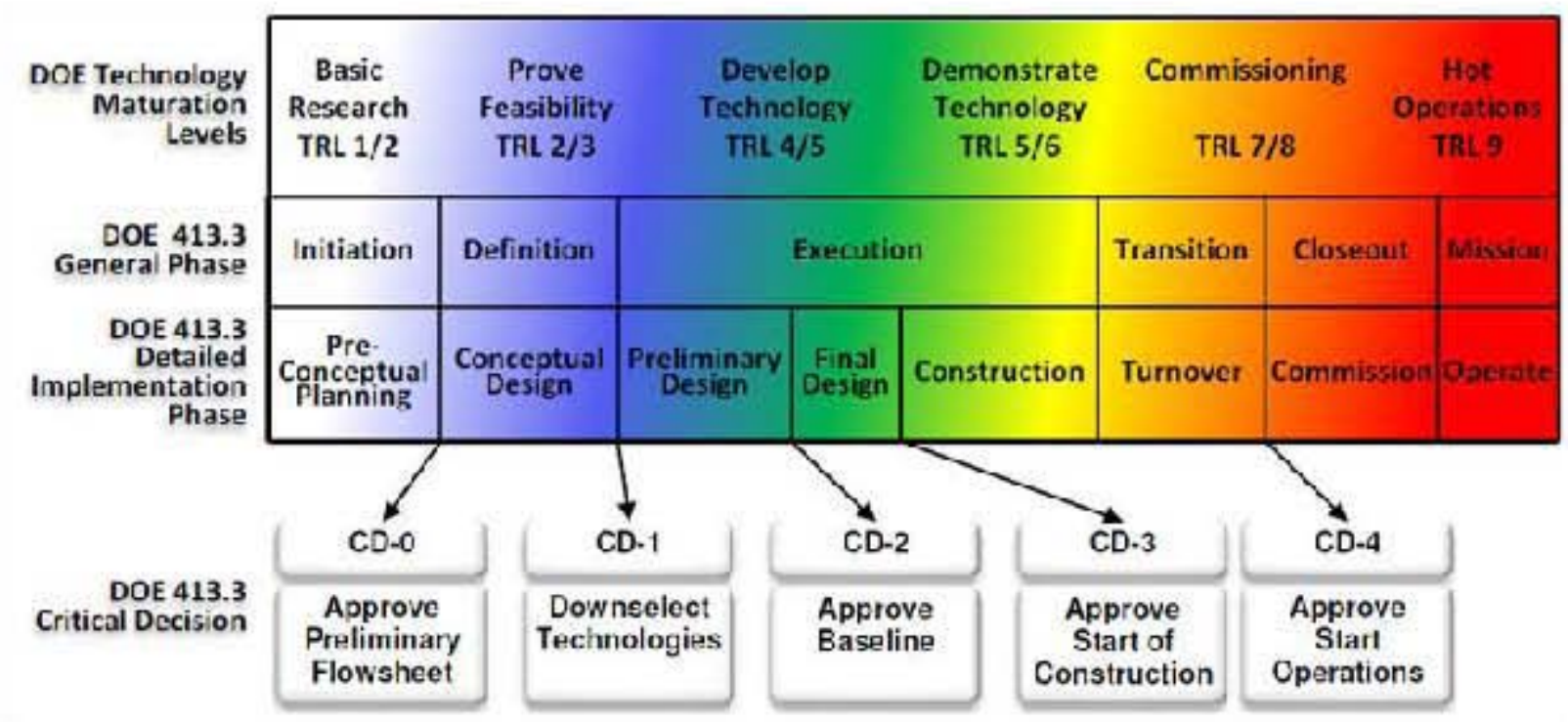

Figure 4-2. Integrated Summary Schedule for Technology Readiness L evel and Critical Decision Process (RPP-RPT-48092, Figure 2-1)

The TRL scale as shown on Figure 4-2 requires that testing of a prototypical design in a relevant environment be completed before incorporating the technology into the final facility design. The TRL levels denote a single numeric level to further understand the relationship between the scale of testing, the fidelity of the testing system, and the environment for relative comparison to other technologies assessed. For ex ample, to achieve a TRL 6 , testing must be completed at an engineering or pilot scale, with testing of the system fidelity that is similar to the actual application, and with a range of simulated waste and a limited range of actual waste.

In 2010, RPP-RPT-48092, Supplemental Treatment Program Technology Readiness Assessment, was prepared. This was a preliminary TRA based on pre-conceptual design information. It concluded that the Cast Stone technology for immobilization of LAW is at TRL 4. Technology Readiness Level 4 is defined as technology development in which component or system validation has occurred in the laboratory environment. It indicates that the basic technological components are integrated to establish that the pieces will work together. Technology Readiness Level 4 is relatively low fidelity compared to the technical maturity required for the eventual system. Technology Readiness Level 4 examples include integration of ad hoc hardware in a laboratory and testing with a range of simulants. The Cast Stone TRL 4 determination along with the rationale is provided in Table 3 below. 
RPP-49062, Rev. 0

\section{Table 3-1. Technology Readiness Level Summary for Cast Stone System}

(RPP-RPT-48092, Table 5-2)

\begin{tabular}{|c|c|c|}
\hline $\begin{array}{l}\text { Critical Technology } \\
\text { Element Description }\end{array}$ & TRL & Rationale \\
\hline $\begin{array}{l}\text { Cast Stone System. The function of } \\
\text { cementitious solidification process is to } \\
\text { receive a treated LAW stream and } \\
\text { produce a containerized, cement-based } \\
\text { waste form that meets the waste } \\
\text { acceptance criteria for IDF. The Cast Stone } \\
\text { technology chemically converts and } \\
\text { incorporates the hazardous and radioactive } \\
\text { constituents of the waste into less soluble, } \\
\text { mobile, or toxic forms to produce a monolithic } \\
\text { solid of high structural strength. Cast stone is a } \\
\text { cement-based, monolithic waste form. It is } \\
\text { unique in that the process is relatively simple } \\
\text { and non-thermal. }\end{array}$ & 4 & $\begin{array}{l}\text { The Cast Stone technology for immobilization of } \\
\text { LAW was determined to be TRL } 4 \text {. The } \\
\text { technology has been demonstrated globally in } \\
\text { industry and other nuclear applications for a wide } \\
\text { range of low- and intermediate level radioactive } \\
\text { waste operations. The technology (Grout } \\
\text { Program) was used at Hanford in a full-scale } \\
\text { capacity in the late } 1980 \text { 's-early } 1990 \text { 's but only } \\
\text { for a limited range of actual waste. A similar } \\
\text { application of the technology is currently being } \\
\text { used at SRS to encapsulate tank waste but has had } \\
\text { limited testing at Hanford since the closeout of the } \\
\text { Grout Program. In addition, the acceptable waste } \\
\text { formulations have not been developed and tested } \\
\text { for use at the Hanford site. A conceptual design } \\
\text { for a Hanford application was completed in } 2003 \text {. } \\
\text { Currently, no ongoing or future technology } \\
\text { development activities are planned to further } \\
\text { advance Cast Stone to a higher TRL. }\end{array}$ \\
\hline
\end{tabular}

\subsubsection{Process Scale up Requirements}

The following provides the status of the Cast Stone system:

- Cast stone waste forms have been produced in the laboratory at less than $1 / 10$ scale. New waste formulations suitable for Hanford LAW need to be developed for the full range of waste feeds that can meet the waste acceptance criteria.

- Although existing technology is minimally qualified as pieces, most hardware components are widely used and available from commercial manufacturers. Standard laboratory scale components such as mixers and hoppers are also available, but will need further development beyond the laboratory-scale components currently qualified for use.

- Testing has been performed with several Hanford based waste streams, including $\mathrm{K}$ Basin sludge, ETF streams, and tank waste, Additional leach testing on Cast Stone and other related waste forms for secondary waste stream has been performed that could serve as a useful input to waste formulations for Cast Stone. However, waste formulations for Hanford LAW have to be developed and tested in order to advance the TRL 4 to a higher level,

- A full-scale pre-conceptual design was completed in 2003 (RPP-RPT-26689), which was not implemented due to unfavorable cost comparison with other immobilization technologies. Since then, essentially no additional Cast Stone technology development has occurred for Hanford LAW. 


\subsection{PROCESS SAFETY CONSIDERATIONS AND CONCERNS}

RPP-RPT-26689 and RPP-RPT-46668, have determined that most of the radionuclides contained in the feed storage tanks are present in quantities less than the threshold for Hazard Category 3; therefore the Cast Stone facility is considered as Hazard Category 3 facility.

The following is a list of typical facility and process hazards that can impact a Cast Stone facility.

- Dust generation

- Flammable gas deflagration, toxic and explosive gas generation due to radiolysis and thermolysis

- Radioactive contamination confinement

- Dose to facility personnel

- Chemical burns due to leaks and spills during waste transfer

- Process area fires from incidental combustible materials

The following is a list of safety considerations that address the hazards listed above, which can result in a safer Cast Stone facility:

- The mixer off-gas, containing displaced air and entrained dry reagent dust generated during the mixing process, is filtered for dust collection in bag houses or scrubbers before being fed to vessel vent processing. This prevents the spread of contamination.

- Control flammable gas concentration by removing ignition sources and providing active or passive ventilation systems. Venting through a filter allows the diffusion of gases and ensures that hydrogen gas does not reach hazardous levels.

- The ventilation system maintains a negative pressure throughout the plant to provide radioactive contamination confinement by collecting the equipment offgases and passing them through redundant HEPA filters and exhaust gas heating to prevent condensation in the filters, before discharging to the stack via the facility HVAC system.

- Non-thermal process with few sources of energetic provides worker safety.

- Employing ALARA principles of time, distance, and shielding minimizes operator dose.

- Control access to process areas. Prevent leaks in primary confinement areas by using robust process piping and tanks. Defense-in-depth for secondary confinement by using encasement hoses for above-grade transfers and double container above-grade lag storage tanks. Fire protection program, non-safety significant fire protections systems, and administrative control of process area.

\subsection{COST CONSIDERATIONS AND CONCERNS}

The major factors that influence the overall construction or operating costs for Cast Stone include the following: 
- Labor and mixer replacement costs, during operations, are substantially higher for continuous mixers versus batch mixers,

- Cast stone facility operations close to IDF,

- Container sizing that is cost effective, technically feasible and compliant with DOE, Department of Transportation (DOT), and NRC regulations,

- Number of shifts per day,

- Decreased shielding costs due to decreased source term,

- Simplicity of process systems,

- Efficiency of process control that achieves zero product defects without bleed water, and

- Substantially higher volume of Cast Stone waste form due to lower Na waste loading (equivalent to $7-8 \%$ of sodium-oxide waste loading).

Cast stone process has low capital and operating costs due to the following reasons:

- It is a non-thermal process which does not require complicated off-process system.

- It does not produce secondary liquid wastes requiring treatment.

- It uses simple batch process with equipment and materials that are readily available.

- It can be operated by available trained operators.

- It does not need elaborate radiological control mechanisms due to lower source term.

\subsection{WASTE FORM CHARACTERISTICS INCLUDING STRENGTHS, WEAKNESSES OR UNCERTAINTIES}

Cast stone is a non-thermal process and the constituents of concern are encapsulated in the monolithic waste form matrix. Long-term performance of the Cast Stone waste form provides the greatest uncertainty. The 2003 preliminary risk analysis indicated the ${ }^{99} \mathrm{Tc}$ leach rate for the Cast Stone ILAW exceeds that of the reference WTP ILAW glass by approximately three orders of magnitude, however, more recent SRS tests predict that the reducing atmosphere provided by blast furnace slag in the Saltstone cementitious waste form would retain ${ }^{99} \mathrm{Tc}$ for more than 10,000 years.

Four Cast Stone waste formulations were laboratory tested in 2005 (RPP-RPT-27297, Development of Cast Stone Formulation for Hanford Tank Waste) in accordance with the following criteria.

- Hydraulic conductivity was measured to determine the permeability using ASTM test method D6527, Test Method for Determining Unsaturated and Saturated Hydraulic Conductivity in Porous Media by Steady-State Centrifugation.

- ANSI/ANS 16.1, Measurement of the Leachability of Solidified Low-Level Radioactive Waste was used to determine the concentration and to calculate the leach rate for $\mathrm{Tc}$, uranium, iodine, nitrate, nitrite, $\mathrm{Cr}$, and $\mathrm{Cs}$. 
- The TCLP was used to test for metals of antimony (Sb), As, barium (Ba), beryllium ( $\mathrm{Be}), \mathrm{Cd}, \mathrm{Cr}(\mathrm{Cr}$, total), lead $(\mathrm{Pb})$, mercury $(\mathrm{Hg})$, nickel $(\mathrm{Ni})$, selenium (Se), Ag, thallium (Tl), vanadium (V), and zinc ( $\mathrm{Zn})$.

- Compression tests were conducted in accordance with ASTM C39/C 39M, Standard Test Method for Compressive Strength of Cylindrical Concrete Specimens.

- Bleed water was determined by ASTM test method C940-98a, Standard Test Method for Expansion and Bleeding of Freshly Mixed Grouts for PreplacedAggregate Concrete in the Laboratory, and is a measure of how much water remains on the top surface of a column of the hydrating waste form after 24-hr curing.

- Product Consistency Test, PUF, and SPFT are not applicable to the Cast Stone waste form and were not used.

The following results were reported for the caste stone waste formulations.

- The best formulation contained $8 \%$ Portland cement, $45 \%$ fly ash (Type F), and $47 \%$ blast furnace slag (Grade 120). The cited formulation contains fly ash which can introduce other RCRA regulated constituents into the waste form, such as, Se, As, etc. that would need to be evaluated for leachability.

- This formulation, with a waste loading of $18.8 \mathrm{wt} \%$ total dissolved solids ( $7.67 \mathrm{wt} \%$ sodium oxide) showed no free-bleed water after $24-\mathrm{hr}$ curing, compressive strengths at least three times the requirement of $500 \mathrm{lb} /$ in. $^{2}$, and negligible hydraulic conductivity.

- Leachability indices were measured for nitrate or nitrite (7.6), $\mathrm{Cr}(13.0),{ }^{99} \mathrm{Tc}$ (9.8), and iodide (greater than 8.6).

- ${ }^{99} \mathrm{Tc}$ leaching was further reduced $38 \%$ by adding bone char. No requirement was identified for the individual leaching indices.

- The TCLP test results met regulatory levels, and all except $\mathrm{Cr}$ met the more stringent Universal Treatment Standards. Subsequently, a nominal addition rate of $1 \%$ ferrous sulfate monohydrate was identified to reduce the $\mathrm{Cr}$ leaching in the mix. Bench-scale tests ( 5 gal) identified a temperature increase of $31^{\circ} \mathrm{C}$ during curing.

Although no additional Cast Stone waste formulations have been developed or tested recently, the Pacific Northwest National Laboratory (PNNL) is testing WTP secondary waste streams to obtain information about the waste form properties that could apply to contaminants of concern in Hanford LAW, particularly ${ }^{99} \mathrm{Tc}$ retention, in developing newer Cast Stone formulations, that could demonstrate compliance with the Hanford waste acceptance criteria for disposal at the IDF (PNNL-19505, Secondary Waste Form Screening Test Results-Cast Stone and Alkali Alumino-Silicate Geopolymer).

Nevertheless, substantial uncertainty in the performance of Cast Stone exists because in the prior formulations it did not compare favorably to other alternatives or meet the disposal criteria. Planned Phase II testing by PNNL for the secondary waste stream will 
focus on waste form development and optimization; mechanisms of radionuclide retention; and regulatory and waste acceptance testing. The Phase II testing results will further answer the question whether the performance of Cast Stone waste form can compare to other alternatives.

\subsection{OFF-GAS TREATMENT REQUIREMENTS AND CONSTITUENTS OF OFF-GAS RELEASED TO THE ATMOSPHERE}

The following provides an evaluation of potential off-gases in the Cast Stone process:

- When Portland cement, fly ash, blast furnace slag, and ferrous sulfate monohydrate are added to LAW, they do not produce any reactions that generate toxic or explosive gases, vapors, or fumes. The heat of hydration of these reagents can increase the rate of gas generation reactions already occurring in the $\mathrm{LAW}$. However, the peak $70^{\circ} \mathrm{C}\left(158^{\circ} \mathrm{F}\right)$ temperature of the ILAW during curing is below levels where gas generation rates could become problematic.

- Radiolytic hydrogen gas generation in the Cast Stone containers is insignificant due to the low radiological source term. The addition of venting through a filter in the container lid, the rapid transport properties of hydrogen gas, and the effect of matrix depletion (reduction of the hydrogen generation rate as the supply of bound hydrogen within the waste is consumed) ensures that hydrogen does not approach hazardous levels during the 90-day interim storage and shipping window period for the Cast Stone containers.

- The corrosion rate of the carbon steel Cast Stone container walls was determined to be less than the vessel wall corrosion rate for LAW in the Hanford double shell tanks. The quantities of gas, vapor, and fumes generated from corrosion were determined to have no potential to harm facility personnel who handle the containers.

- Based on the evaluations in RPP-RPT-26689, it is concluded that neither radiolytic hydrogen nor chemical gas generation pose an explosive or toxic hazard to workers from the Cast Stone process.

\subsection{SECONDARY WASTE STREAMS AND THEIR MANAGEMENT}

The following provides an evaluation of potential secondary waste streams in the Cast Stone process:

- Condensates are used in place of clean water and recycled following removal of solid materials. Flush water and other non-evaporated liquid wastes are reincorporated into the primary waste stream and excess water is evaporated.

- Secondary non-process wastes such as filters and other consumables, failed equipment, industrial wastes, and personnel protective equipment wastes are produced and disposed in accordance with Hanford standards and practices.

Based on the evaluations in RPP-RPT-26689, it is concluded that secondary waste streams are not significant in the Cast Stone process. 


\subsection{INFORMATION NEEDS}

This section provides a list of existing data gaps that must be addressed in order to advance the Cast Stone technology to the next TRL.

\subsection{WHAT ARE THE DATA GAPS?}

It is estimated that approximately two to three years of development and testing would be required to formulate an acceptable cementitious waste form for LAW immobilization.

The following data gaps exist at the present time, which will need to be completed in order to advance the TRL to the next level, i.e. TRL 5 or 6.

- Establishing the waste form acceptance criteria

- Developing and testing waste formulations for the selected range of waste feeds to meet the waste form acceptance criteria and understand long term performance

- Developing lab tests with actual Hanford LAW and statistical coring of samples

- Defining the specifications for the equipment and components used in the Cast Stone process

- Establishing Hanford LAW feed receipt and feed delivery criteria and testing an appropriate range of waste feeds.

\subsection{RISKS AND BENEFITS}

\subsection{KEY TECHNICAL AND PROGRAMMATIC RISKS}

This section discusses the existing key technical and programmatic risks and the steps that need to be taken to mitigate these existing risks. Benefits and principal advantage of the Cast Stone technology are also discussed.

- Long term performance: Acceptability of Cast Stone as a primary Hanford immobilization LAW waste form is uncertain at present due to lack of testing data on ${ }^{99} \mathrm{Tc}$ retention with advanced Cast Stone formulations. Newer Cast Stone formulations for secondary waste stream are providing encouraging test data but there is no testing data that can conclusively show ${ }^{99} \mathrm{Tc}$ retention in Hanford LAW for the periods of time typically evaluated during a performance assessment. Therefore further development of the Cast Stone technology has to occur, which will need to demonstrate acceptable performance.

- Stakeholder acceptance: An immobilization option such as Cast Stone will need to show the minimization of long-term risk to ground water from waste disposed onsite. The long-term risks to ground water from constituents of concern include ${ }^{129}$ Iodine, ${ }^{99} \mathrm{Tc}, \mathrm{U}, \mathrm{Cr}$, and nitrate. Technetium-99 is one of the key drivers of risk in Hanford tank waste and is a very mobile, long-lived radionuclide. Stakeholders believe that Cast Stone product does not compare favorably against other alternative waste forms in terms of long-term performance. Further development of newer Cast 
Stone formulations and extensive testing can help provide confidence to stakeholders on the potential viability of Cast Stone.

- Waste volume: The volume of immobilized Cast Stone product is significantly greater than for other waste forms, approximately twice the volume of WTP LAW glass.

\subsection{BENEFITS AND PRINCIPAL ADVANTAGES}

- Cast stone is a simple, non thermal process, which does not volatilize constituents of concern

- Cast stone process is used extensively and successfully in the DOE complex, commercial nuclear and hazardous waste industries

- Cast stone process is conducted at room temperature using a relatively simple off-gas system

- Cast stone process does not volatilize Tc and iodine at process conditions

- Cast stone process does not generate NOx requiring elaborate process systems

- Low life-cycle capital and operating costs

- Cast stone facility can maintain sufficient "freeboard" in storage tanks to accept LAW feed from the upstream treatment system

- Cast stone facility staffing is sufficient for meeting production goals

\subsection{HOW WILL THE RISKS BE MITIGATED?}

No development work on Cast Stone for Hanford LAW has been undertaken recently. However, a study was completed in June 2010, PNNL-19505, Secondary Waste Form Screening Test Results-Cast Stone and Alkali Alumino-Silicate Geopolymer, for supporting the stabilization and solidification of liquid secondary waste stream from the WTP.

Key technical and programmatic risks can be mitigated by:

- Incorporating the results from the PNNL study, even though the Hanford LAW waste stream is different than the secondary waste stream. The study indicated that the next phase of testing of the Cast Stone for the secondary waste stream will provide additional information about the waste form properties to support a final down-selection to a waste form for the WTP secondary waste streams sent to ETF for solidification.

- Completing Phase II testing to obtain and evaluate information that may be of potential use in developing Cast Stone for the Hanford LAW waste stream. The Phase II test results are germane as it is the only ongoing development work in recent years, the simulants are relative to WTP contaminants of concern, and the Cast Stone formulations, and applied technology processes are similar.

- The Phase II testing will focus on three areas: 
RPP-49062, Rev. 0

- waste form development and optimization

- mechanisms of radionuclide retention

- regulatory and waste acceptance testing. 


\subsection{REFERENCES}

10 CFR 61, "Licensing Requirements for Land Disposal of Radioactive Waste" Code of Federal Regulations.

15 USC 2601 et seq., Toxic Substances Control Act of 1976, Code of Federal Regulations, as amended.

40 CFR 261, "Identification and Listing of Hazardous Waste," Code of Federal Regulations, as amended.

42 USC 6901, et seq., Resource Conservation and Recovery Act of 1976 (RCRA).

ANSI/ANS 16.1, Measurement of the Leachability of Solidified Low-Level Radioactive Waste ASTM B553-79, Test Method for Thermal Cycling of Electroplated Plastics, ASTM International, ASTM International.

ASTM test method C940-98a, Standard Test Method for Expansion and Bleeding of Freshly Mixed Grouts for Preplaced-Aggregate Concrete in the Laboratory, ASTM International.

ASTM C39/C 39M, Standard Test Method for Compressive Strength of Cylindrical Concrete Specimens, ASTM International.

ASTM WK84, Test Method for Measuring Waste Glass Durability by Vapor Hydration Test. ASTM International.

ASTM C1662-10, Standard Practice for Measurement of the Glass Dissolution Rate Using the Single-Pass Flow-Through Test Method, ASTM International. ASTM International.

ASTM G21-96, Standard Practice for Determining Resistance of Synthetic Polymeric Materials to Fungi, ASTM International.

ASTM G22-76, Standard Practice for Determining Resistance of Plastics to Bacteria. ASTM International.

ASTM test method D6527, Test Method for Determining Unsaturated and Saturated Hydraulic Conductivity in Porous Media by Steady-State Centrifugation, ASTM International.

Bernero, 1993, Letter from R.M. Bernero, Director, Office of Nuclear Materials Safety and Safeguards, U.S. Nuclear Regulatory Commission, Washington, D.C., to J. Lytle, Deputy Assistant Secretary for Waste Operations, Office of Environmental Restoration and Waste Management, U.S. Department of Energy, Washington, D.C., March 2, 1993.

C. Jantzen, N. Bibler, D. Beam, and W. Ramsey, "Development of an ASTM Standard Glass Durability Test, the Product Consistency Test (PCT), for High Level Radioactive Waste Glass," 1994, Proceedings of Spectrum 94 Nuclear and Hazardous Waste Management International Topical Meeting, Am. Nuclear Soc., 164-169.

DOE O 413.3A, 2006, Program and Project Management for the Acquisition of Capital Assets, Change 1, U.S. Department of Energy, Washington, D.C.

DOE M 435.1-1, Radioactive Waste Management Manual, U.S. Department of Energy, Washington, D.C. 
DOE-STD-1027-92, 1997, Hazard Categorization and Accident Analysis Techniques for Compliance with DOE Order 5480.23, Nuclear Safety Analysis Reports, Change Notice No. 1, U.S. Department of Energy, Washington, D.C.

DOE 1996, Technical Basis for Classification of Low-Activity Waste Fraction from Hanford Site Tanks, Westinghouse Hanford Company, Los Alamos Technical Associates, Inc., BNFL, Inc., WHC-SD-WM-TI-699, Rev 2, September 1996.

DOE 1997, Tank Waste Remediation System (TWRS) Environmental Impact Statement (EIS) Record of Decision (ROD)

DOE 2008, Technology Readiness Assessment (TRA) / Technology Maturation Plan (TMP)

Process Guide, U.S. Department of Energy, Office of Environmental Management, Engineering and Technology, Washington, D.C.

IDF 2004, Integrated Disposal Facility Waste Acceptance Criteria, CEES-0134, Rev. B, prepared by Columbia Energy \& Environmental Services, Inc. for CH2M Hill Hanford Group, Inc., Richland, WA, August 18, 2004. NRC 1997, Letter from Carl J. Papariello, Director, Office of Nuclear Material Safety and Safeguards, U.S. Nuclear Regulatory Commission, Washington, D.C., to Jackson Kinzer, Assistant Manager, Office of Tank Waste Remediation System, U.S. Department of Energy, Richland, WA, Classification of Hanford Low-Activity Waste Fraction, July 1997.

National Environmental Policy Act of 1969 (NEPA) Pub. L. 91-190, 42 U.S.C. 4321-4347, January 1, 1970, as amended by Pub. L. 94-52, July 3, 1975, Pub. L. 94-83, August 9, 1975, and Pub. L. 97-258, § 4(b), Sept. 13, 1982.

NWPA 1983, Nuclear Waste Policy Act of 1983, Public Law 97-425; 96 Stat. 2201.

ORP-11242, 2010, Rev 5, River Protection Project System Plan, U.S. DOE, Office of River Protection, Richland, Washington.

PNL-7838, 1992, Durability of Double-Shell Slurry Feed Grouts: FY-90 Results, Pacific Northwest National Laboratory, Richland, Washington.

PNNL-18196, 2009, Hanford Site Secondary Waste Roadmap, Pacific Northwest National Laboratory, Richland, Washington.

PNNL-19505, 2010, Secondary Waste Form Screening Test Results-Cast Stone and Alkali Alumino-Silicate Geopolymer, Pacific Northwest National Laboratory, Richland, Washington.

Resource Conservation and Recovery (RCRA) Act of 1976, 42 USC 6901, et seq.

RPP-48395, 2011, A Joule-Heated Melter Technology for the Treatment and Immobilization of Low-Activity Waste, Rev. 0, Washington River Protection Solutions, LLC, Richland, Washington..

RPP-48703, 2011, Bulk Vitrification Technology for the Treatment and Immobilization of LowActivity Waste, Rev. 0, Washington River Protection Solutions, LLC, Richland, Washington. 
RPP-48903, 2011, Fluidized Bed Steam Reforming for the Treatment and Immobilization of Low-Activity Waste, Rev. 0, Washington River Protection Solutions, LLC, Richland, Washington.

RPP-8402, 2002, Waste Acceptance Criteria for the Immobilized Low-Activity Waste Disposal Facility, Rev. 0, CH2M HILL Hanford Group, Inc., Richland, Washington.

RPP-15834, 2003, Integrated Disposal Facility Risk Assessment, CH2M HILL Hanford Group, Inc., Richland, Washington.

RPP-17675, 2003, Risk Assessment Supporting the Decision on the Initial Selection of Supplemental ILAW Technologies, CH2M HILL Hanford Group, Inc., Richland, Washington.

RPP-CALC-48104, 2010, 200 Area Supplemental Treatment and Immobilization System Capacity, Rev.0, Washington River Protection Solutions, LLC, Richland, Washington.

RPP-PLAN-47413, 2010, Hanford Site Tank Waste Research and Development Plans, Rev. 0, Washington River Protection Solutions, LLC, Richland, Washington.

RPP-RPT-26689, 2003, Containerized Cast Stone Project 100 Percent Pre-Conceptual Design Documentation, Rev. 0, CH2M HILL Hanford Group, Inc., Richland, Washington.

RPP-RPT-26742, 2005, Hanford Containerized Cast Stone Facility, CH2M HILL Hanford Group, Inc., Richland, Washington.

RPP-RPT-27297, 2005, Development of Cast Stone Formulation for Hanford Tank Waste, CH2M HILL Hanford Group, Inc., Richland, Washington.

RPP-RPT-26725, 2008, Cast Stone Technology for Treatment and Disposal of Iodine-Rich Caustic Waste Demonstration - Final Report, Rev. 0-A, CH2M HILL Hanford Group, Inc., Richland, Washington.

RPP-RPT-46668, 2010, Supplemental Treatment Pre Conceptual Engineering Review, Rev. 0, Washington River Protection Solutions, LLC, Richland, Washington.

RPP-RPT-48092, 2010, Supplemental Treatment Project Technology Readiness Assessment, Rev. 0, Draft Report, Washington River Protection Solutions, LLC, Richland, Washington.

WAC 173-303, "Dangerous Waste Regulations," Washington Administrative Code, as amended. 


\subsection{GLOSSARY OF TERMS}

Deflagration is a technical term describing combustion that usually propagates through thermal conductivity, when hot burning material heats the next layer of cold material and ignites it. Most "fire" found in daily life, from flames to explosions, is technically deflagration. Deflagration is different from detonation, which propagates through shock compression.

Getter is a substance that preferentially reacts with contaminants of concern, like ${ }^{99} \mathrm{Tc}$, and helps to retain them in the waste form.

Hanford Integrated Disposal Facility (IDF) is a low-level waste and mixed low-level waste disposal facility on the Hanford site that will be used to dispose of immobilized LAW as well as secondary wastes produced by tank farm and treatment operations.

HLVIT Standards (not an acronym) is a RCRA Universal Treatment Standard (UTS) that requires the vitrification of high-level radioactive waste generated during the reprocessing of fuel rods mixed with characteristic metal wastes. It was promulgated in the Third Rule at $55 \mathrm{FR}$ 22626 (June 1, 1990). The Third Rule stated that all the promulgated treatment standards in that rule for RCRA listed and characteristic wastes apply to the RCRA hazardous portion of mixed radioactive (high-level, TRU, and low-level) wastes, unless EPA has specifically established a separate treatability group for a specific category of mixed waste. Thus, that rule required that radioactive waste mixed with metal characteristic waste would have to comply with the LDR treatment standard for the metal characteristic waste, as well as any requirements set forth by the $\mathrm{NRC}$ for the radioactive component of the mixed waste.

Low-Activity Waste $(L A W)$ refers to Hanford tank waste that has been treated to remove key radionuclides to the maximum extent technically and economically practical, converted to a solid form that meets $10 \mathrm{CFR}$ Part 61.55 Class $\mathrm{C}$ concentration limits, and demonstrated through a formal performance assessment to meet performance objectives comparable to those set forth in 10 CFR Part 61, Subpart C.

Performance Assessment (PA) refers to detailed analyses conducted to determine whether the protection provided by disposal sites, engineered barriers, and active and passive institutional barriers is adequately protective of human health and the environmental relative to applicable laws and regulations pertaining to the disposal radioactive or hazardous materials considering natural and human-caused processes and events that could affect that protection.

Pozzolanic materials are often non-radioactive, waste materials (e.g., fly ash or blast furnace slag) that aid in retaining waste materials and forming a solid monolith.

Radiolysis is the dissociation of molecules by radiation. It is the cleavage of one or several chemical bonds resulting from exposure to high-energy flux. Radiolysis can locally modify REDOX conditions, and therefore the speciation and the solubility of the compounds.

Resource Conservation and Recovery Act (RCRA), enacted by Congress in 1976, is the principal Federal law in the United States governing the disposal of solid waste and hazardous waste. The Washington Department of Ecology under RCRA regulates the Hanford tank wastes and systems used for the treatment of those wastes. 
Thermolysis is a chemical decomposition caused by heat. The reaction is usually endothermic as heat is required to break chemical bonds in the compound undergoing decomposition. The decomposition temperature of a substance is the temperature at which the substance chemically decomposes. If decomposition is sufficiently exothermic, a positive feedback loop is created producing thermal runaway and possibly an explosion. 